Published in "Tetrahedron 74(1): 28-41, 2018"

which should be cited to refer to this work.

\title{
Puckering behavior in six new phosphoric triamides containing aliphatic six- and seven-membered ring groups and a database survey of analogous ring-containing structures
}

\author{
Banafsheh Vahdani Alviri a , Mehrdad Pourayoubi ${ }^{a}{ }^{*}$, Anahid Saneei ${ }^{a}$, Mojtaba Keikha ${ }^{\text {a }}$ \\ Arie van der Lee ${ }^{b}$, Aurélien Crochet ${ }^{c}$, A. Abdul Ajees ${ }^{\mathrm{d}}$, Marek Nečas ${ }^{\mathrm{e}}$, ${ }^{\mathrm{f}}$, \\ Katharina M. Fromm ${ }^{c}$, Krishnan Damodaran ${ }^{g}$, Titus A. Jenny ${ }^{\mathrm{h}}$ \\ a Department of Chemistry, Faculty of Sciences, Ferdowsi University of Mashhad, Mashhad, Iran \\ ${ }^{\mathrm{b}}$ Institut Européen des Membranes, Université de Montpellier, 34095 Montpellier, France \\ ${ }^{\mathrm{c}}$ Fribourg Centre for Nanomaterials, FriMat, University of Fribourg, Department of Chemistry, Chemin du Musée 9, CH-1700 Fribourg, Switzerland \\ ${ }^{\mathrm{d}}$ Department of Atomic and Molecular Physics, Manipal Institute of Technology, Manipal University, Manipal, Karnataka 576 104, India \\ e Department of Chemistry, Masaryk University, Kotlarska 2, 61137 Brno, Czech Republic \\ CEITEC - Central European Institute of Technology, Masaryk University, Kamenice 5, 62500 Brno, Czech Republic \\ ${ }^{g}$ Department of Chemistry, University of Pittsburgh, Pittsburgh, PA 15260, USA \\ h Department of Chemistry, University of Fribourg, Rte du Musée 9, Ch-1700 Fribourg, Switzerland
}

\begin{abstract}
The influence of a $\mathrm{N}$ heteroatom on the ring conformations of six- and seven-membered aliphatic rings in six new $\mathrm{C}(\mathrm{O}) \mathrm{NHP}(\mathrm{O})$-based phosphoric triamide structures (analysed by X-ray crystallography) is investigated. Additionally the influence of steric and crystal packing effects is also studied by the analysis of Hirshfeld surfaces. The results are compared to analogous structures with three- to seven- aliphatic membered rings deposited in the Cambridge Structural Database. In the newly determined structures, the six-membered rings only show the near-chair conformation with a maximum deviation of the $\theta$ puckering parameter of $4.4^{\circ}$ from the ideal chair value of $0^{\circ} / 180^{\circ}$, while the seven-membered rings are found in different conformations such as near-chair, twist chair and twist sofa.
\end{abstract}

Keywords:

Puckering parameter

Six-member ring

Seven-member ring

Phosphoric triamide

Hydrogen bond pattern

Cambridge Structural Database

\section{Introduction}

Conformational studies of non-rigid rings/segments attract much interest not only because of the diversity of different topologies found, but also due to their pharmacological importance in biological systems and the possible induction of chirality in the solid state. ${ }^{1-5}$ Different techniques have been used for the determination of ring conformations including X-ray crystallography, computational calculation and NMR spectroscopy. ${ }^{6-11}$ Puckering parameters, obtained from single crystal X-ray experiments, were employed for defining the ring conformations of four- to ninemembered rings. ${ }^{12-17}$

\footnotetext{
* Corresponding author.

E-mail address: pourayoubi@um.ac.ir (M. Pourayoubi).
}

A general definition of ring puckering coordinates has been established by Cremer and Pople (1975), ${ }^{18}$ who proposed the analysis of puckered forms of an $\mathrm{N}$-membered ring by calculating the mean plane (MP) and the puckering parameters of the ring. ${ }^{18}$ This approach is a generalization of the description of a puckered cyclopentane ring first given by Kilpatrick, Pitzer and Spitzer (1947), ${ }^{19}$ and is a systematic way for the description of ring conformations. Cremer and Pople defined parameters for associating the shape of a puckered ring, its conformation, and its interconversional motions using a mathematically well-defined subset of internal coordinates. ${ }^{20}$ The ring-puckering coordinates, according to this method yield three puckering degrees of freedom $(Q, \theta$ and $\varphi)$ for six-membered rings, ${ }^{18}$ while for seven-membered rings the general definition noted was developed and four puckering parameters, namely two amplitudes $q_{2}$ and $q_{3}$ and two phases of $\varphi_{2}$ and $\varphi_{3}$, were defined. ${ }^{21}$ 
The relationship between conformational properties and pharmacological activities was investigated for different structures belonging to different families of compounds, such as peptidebased HIV protease inhibitors, terpenic lactone-based anti-cancer drugs and histamine derivatives-based drug-receptors. ${ }^{22-24}$ For phosphorus containing compounds with interesting biological properties, different conformational studies have been reported which mostly focussed on the non-ring segments with free or restricted rotations, such as tert- $\mathrm{C}_{4} \mathrm{H}_{9} \mathrm{NH}$ and $\mathrm{N}(\mathrm{R})\left(\mathrm{CH}_{2} \mathrm{C}_{6} \mathrm{H}_{5}\right)$ compounds, ${ }^{25,26}$ the conformation of the lone electron pair located at the nitrogen atom with respect to $\mathrm{P}=\mathrm{X}(\mathrm{X}=\mathrm{O}$ and $\mathrm{S})$ in compounds including $(\mathrm{N}) \mathrm{P}=\mathrm{X}$ segment ${ }^{27}$ and the conformations of $\mathrm{C}=\mathrm{O}$ versus $\mathrm{P}=\mathrm{O}$ in $\mathrm{C}(\mathrm{O}) \mathrm{NHP}(\mathrm{O})$-based structures. ${ }^{28}$ With respect to the ring segment, the conformations of six-membered phosphorus-containing heterocyclic rings were extensively studied in phosph(on) ates with anti-tumor activity or a potent prodrug role against the liver diseases hepatitis B and $C .{ }^{29,30}$ The puckering behavior of chelate complexes with ligands including $\mathrm{C}(\mathrm{O}) \mathrm{NHP}(\mathrm{O}),(\mathrm{X}) \mathrm{NP}(\mathrm{O})$ $\left[\mathrm{X}=\mathrm{C}(\mathrm{O}), \mathrm{C}(\mathrm{S}), \mathrm{S}(\mathrm{O})_{2}\right.$ and $\left.\mathrm{P}(\mathrm{O})\right]$ and $\mathrm{O}\left[\mathrm{P}(\mathrm{O})(\mathrm{N})_{2}\right]_{2}$ was studied as well. $^{31}$
With this background in mind, we present here a detailed puckering analysis for $\mathrm{C}(\mathrm{O}) \mathrm{NHP}(\mathrm{O})$-based phosphoric triamides including six- and seven-membered aliphatic rings in order to rationalize the parameters influencing these conformations. Six new six- and seven-membered ring-containing compounds were designed and synthesized including examples with only carbon atoms in the skeleton of ring (namely cyclo- "C6" and cyclo- "C7") and with rings including one nitrogen heteroatom (cyclo- "C5N" and cyclo- "C6N") according to Scheme 1. The geometrical deviation caused by the presence or absence of the $\mathrm{N}$ heteroatom is studied, and a comparison of angles in the $\mathrm{C}-\mathrm{N}-\mathrm{C} / \mathrm{C}-\mathrm{C}-\mathrm{C}$ segments is made in the rings of the new structures. A supplementary analysis was done by a Cambridge Structural Database (CSD) survey on analogous structures with three- to seven- aliphatic membered rings. The steric and packing effects were also studied and a Hirshfeld surface analysis was performed on the newly determined structures in order to study the packing effect in detail and the deviations induced by different intermolecular interactions.

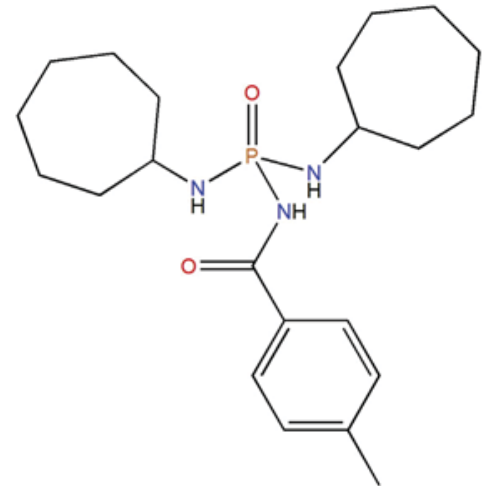

1

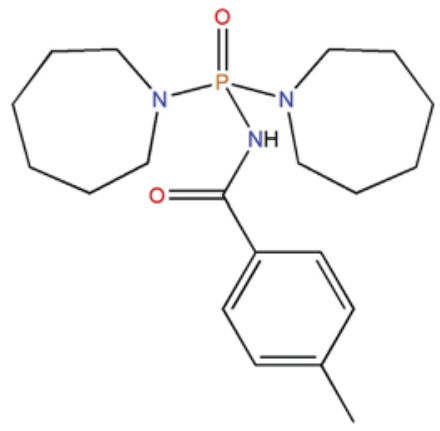

3

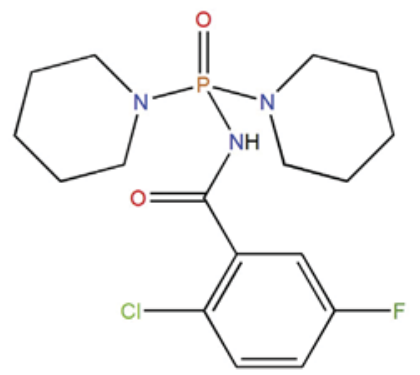

5

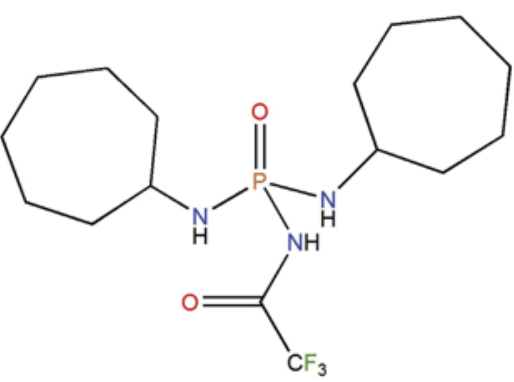

2

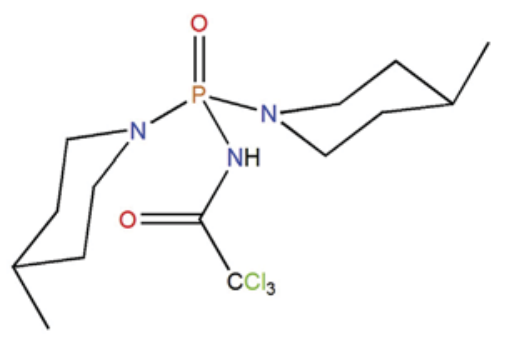

4

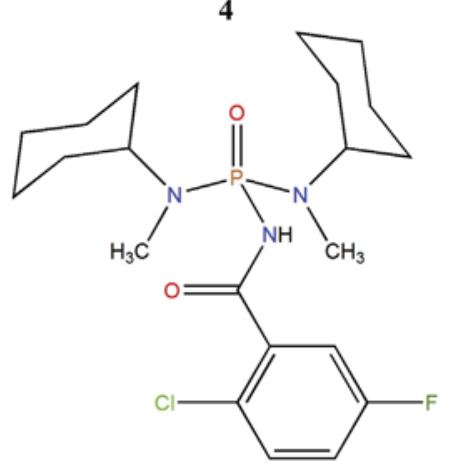

6

Scheme 1. Chemical structures of 1-6. 


\section{Results and discussion}

\subsection{Crystal structure description}

Details of the data collection and structure refinement are summarized in Tables 1 and 2. The asymmetric units of all six structures are composed of one complete molecule (Figs. 1-6).
Selected bond lengths and angles and hydrogen bonds geometries are listed in Tables 3-5. The general features of the molecular structures of $1,2,3,4,5$ and 6 are very similar, and the bond lengths and angles are within the expected values observed for analogous structures. ${ }^{32}$ So, we limit the general discussion to that for structure 1. If, however, any structure has a structural feature deviating from that of the general observations, it will be discussed as well.

Table 1

Crystal data and structure refinement for compounds $\mathbf{1}-\mathbf{3}$.

\begin{tabular}{|c|c|c|c|}
\hline & 1 & 2 & 3 \\
\hline Empirical formula & $\mathrm{C}_{22} \mathrm{H}_{36} \mathrm{~N}_{3} \mathrm{O}_{2} \mathrm{P}$ & $\mathrm{C}_{16} \mathrm{H}_{29} \mathrm{~F}_{3} \mathrm{~N}_{3} \mathrm{O}_{2} \mathrm{P}$ & $\mathrm{C}_{20} \mathrm{H}_{32} \mathrm{~N}_{3} \mathrm{O}_{2} \mathrm{P}$ \\
\hline Formula weight & 405.51 & 383.39 & 377.45 \\
\hline Temperature (K) & 250 & 120 & 200 \\
\hline Wavelength ( & 0.71073 & 0.71073 & 0.71073 \\
\hline Crystal system & Monoclinic & Monoclinic & Monoclinic \\
\hline Space group & $P 2_{1} / c$ & $P 2_{1} / c$ & $P 2_{1} / n$ \\
\hline$a(\AA)$ & $9.96143(3)$ & $16.5623(3)$ & $10.2207(4)$ \\
\hline$b(\AA)$ & $19.1754(6)$ & $4.9423(1)$ & $8.8955(4)$ \\
\hline$c(\AA)$ & $11.7209(4)$ & $23.0389(4)$ & $22.1458(7)$ \\
\hline$\alpha\left({ }^{\circ}\right)$ & 90 & 90 & 90 \\
\hline$\beta\left({ }^{\circ}\right)$ & $96.999(2)$ & $92.560(2)$ & $95.422(3)$ \\
\hline$\gamma\left({ }^{\circ}\right)$ & 90 & 90 & 90 \\
\hline Volume $\left(\AA^{3}\right)$ & $2222.17(12)$ & $1883.99(6)$ & $2004.45(14)$ \\
\hline$Z$ & 4 & 4 & 4 \\
\hline Density (calculated) $\left(\mathrm{g} / \mathrm{cm}^{3}\right)$ & 1.212 & 1.352 & 1.251 \\
\hline Absorption coefficient $\left(\mathrm{mm}^{-1}\right)$ & 0.15 & 0.19 & 0.16 \\
\hline$F(000)$ & 880 & 816 & 816 \\
\hline Index ranges & $\begin{array}{l}-11 \leq h \leq 11,-22 \leq k \leq 22 \\
-13 \leq l \leq 13\end{array}$ & $\begin{array}{l}-19 \leq h \leq 19,-5 \leq k \leq 5 \\
-27 \leq l \leq 27\end{array}$ & $\begin{array}{l}-12 \leq h \leq 12,-10 \leq k \leq 10 \\
-24 \leq l \leq 26\end{array}$ \\
\hline Reflections collected & 26038 & 11144 & 24935 \\
\hline Independent reflections & $3934[R($ int $)=0.036]$ & $3410\left[R\left({ }_{\text {int }}\right)=0.021\right]$ & $3554[R($ int $)=0.037]$ \\
\hline Refinement method & Full-matrix least-squares on $F^{2}$ & Full-matrix least-squares on $F^{2}$ & Full-matrix least-squares on $F^{2}$ \\
\hline Data/restraints/parameters & $3934 / 185 / 328$ & $3410 / 3 / 235$ & $3554 / 1 / 233$ \\
\hline Goodness-of-fit on $F^{2}$ & 1.062 & 1.04 & 1.07 \\
\hline Final $R$ indices $[I>2 \sigma(I)]$ & $R_{1}=0.0444, w R_{2}=0.1207$ & $R_{1}=0.0403, w R_{2}=0.0997$ & $R_{1}=0.0416, w R_{2}=0.1148$ \\
\hline$R$ indices (all data) & $R_{1}=0.0588, w R_{2}=0.1300$ & $R_{1}=0.0459, w R_{2}=0.1039$ & $R_{1}=0.0510, w R_{2}=0.1200$ \\
\hline $\begin{array}{l}\text { Largest diff. peak } \\
\quad \text { and hole }\left(e . \AA^{-3}\right)\end{array}$ & 0.53 and -0.26 & 0.57 and -0.39 & 0.85 and -0.40 \\
\hline
\end{tabular}

Table 2

Crystal data and structure refinement for compounds 4-6.

\begin{tabular}{|c|c|c|c|}
\hline & 4 & 5 & 6 \\
\hline Empirical formula & $\mathrm{C}_{14} \mathrm{H}_{25} \mathrm{Cl}_{3} \mathrm{~N}_{3} \mathrm{O}_{2} \mathrm{P}$ & $\mathrm{C}_{17} \mathrm{H}_{24} \mathrm{ClFN}_{3} \mathrm{O}_{2} \mathrm{P}$ & $\mathrm{C}_{21} \mathrm{H}_{32} \mathrm{ClFN}_{3} \mathrm{O}_{2} \mathrm{P}$ \\
\hline Formula weight & 404.69 & 387.81 & 443.92 \\
\hline Temperature (K) & 293 & 175 & 175 \\
\hline Wavelength $(\AA)$ & 0.71073 & 0.71073 & 0.71073 \\
\hline Crystal system & Monoclinic & Triclinic & Triclinic \\
\hline Space group & $P 2_{1} / n$ & $P \overline{1}$ & $P \overline{1}$ \\
\hline$a(\AA)$ & $11.2890(6)$ & $9.8874(7)$ & $10.2155(6)$ \\
\hline$b(\AA)$ & $10.1740(2)$ & $9.9826(6)$ & $10.6848(7)$ \\
\hline$c(\AA)$ & $17.4990(4)$ & $11.1284(6)$ & $11.4544(6)$ \\
\hline$\alpha\left({ }^{\circ}\right)$ & 90 & $101.147(5)$ & $68.784(5)$ \\
\hline$\beta\left({ }^{\circ}\right)$ & $92.311(3)$ & $114.924(6)$ & $80.429(5)$ \\
\hline$\gamma\left({ }^{\circ}\right)$ & 90 & $98.096(5)$ & $81.374(5)$ \\
\hline Volume $\left(\AA^{3}\right)$ & $2008.20(12)$ & $946.32(5)$ & $1143.79(6)$ \\
\hline Z & 4 & 2 & 2 \\
\hline Density (calculated) $\left(\mathrm{g} / \mathrm{cm}^{3}\right)$ & 1.339 & 1.361 & 1.289 \\
\hline Absorption coefficient $\left(\mathrm{mm}^{-1}\right)$ & 0.55 & 0.31 & 0.27 \\
\hline$F(000)$ & 848 & 407.998 & 472 \\
\hline Index ranges & $\begin{array}{l}-15 \leq h \leq 15,-13 \leq k \leq 12, \\
-23 \leq l \leq 23\end{array}$ & $\begin{array}{l}-13 \leq h \leq 11,-13 \leq k \leq 12 \\
-14 \leq l \leq 14\end{array}$ & $\begin{array}{l}-13 \leq h \leq 12,-14 \leq k \leq 13 \\
-15 \leq l \leq 15\end{array}$ \\
\hline Reflections collected & 18455 & 9148 & 13331 \\
\hline Independent reflections & $5012[R(\mathrm{int})=0.029]$ & $4162[R(\mathrm{int})=0.037]$ & $5367[R(\mathrm{int})=0.039]$ \\
\hline Refinement method & Full-matrix least-squares on $F^{2}$ & Full-matrix least-squares on $F^{2}$ & Full-matrix least-squares on $F^{2}$ \\
\hline Data/restraints/parameters & $5012 / 0 / 238$ & $4162 / 3 / 229$ & $5367 / 3 / 265$ \\
\hline Goodness-of-fit on $F^{2}$ & 1.07 & 0.94 & 0.91 \\
\hline Final $R$ indices $[I>2 \sigma(I)]$ & $R_{1}=0.0510, w R_{2}=0.1386$ & $R_{1}=0.0440, w R_{2}=0.1161$ & $R_{1}=0.0558, w R_{2}=0.1357$ \\
\hline$R$ indices (all data) & $R_{1}=0.0840, w R_{2}=0.1581$ & $R_{1}=0.0557, w R_{2}=0.1259$ & $R_{1}=0.0707, w R_{2}=0.1529$ \\
\hline $\begin{array}{l}\text { Largest diff. peak } \\
\text { and hole }\left(\mathrm{e} . \AA^{-3}\right)\end{array}$ & 0.46 and -0.51 & 0.49 and -0.42 & 0.37 and -1.00 \\
\hline
\end{tabular}




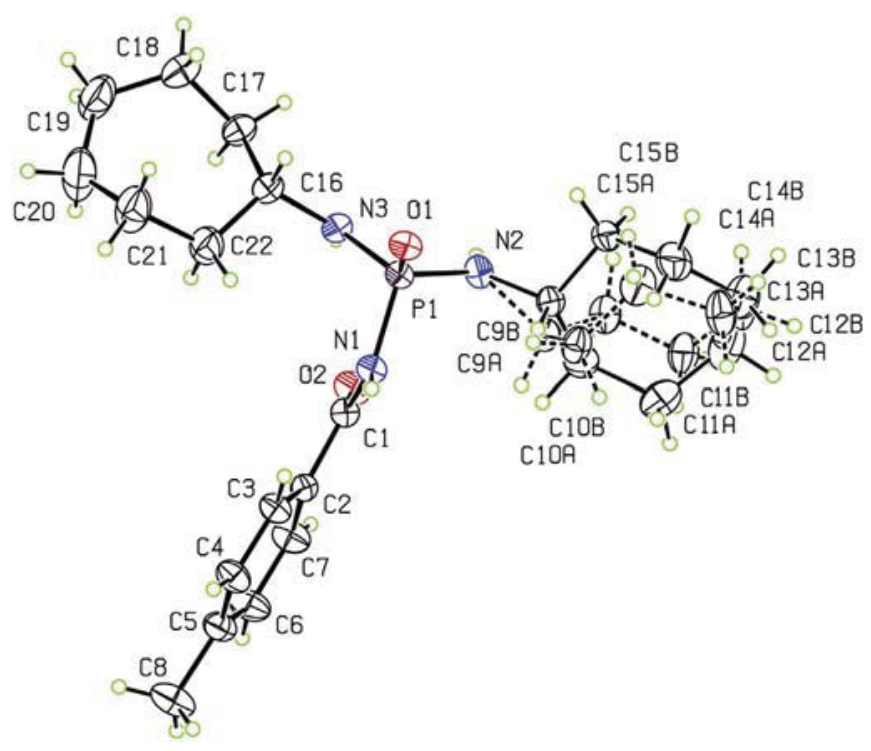

Fig. 1. Displacement ellipsoid plot (30\% probability level) for structure 1, with atom-numbering scheme. Dashed lines indicate the minor-disorder component.

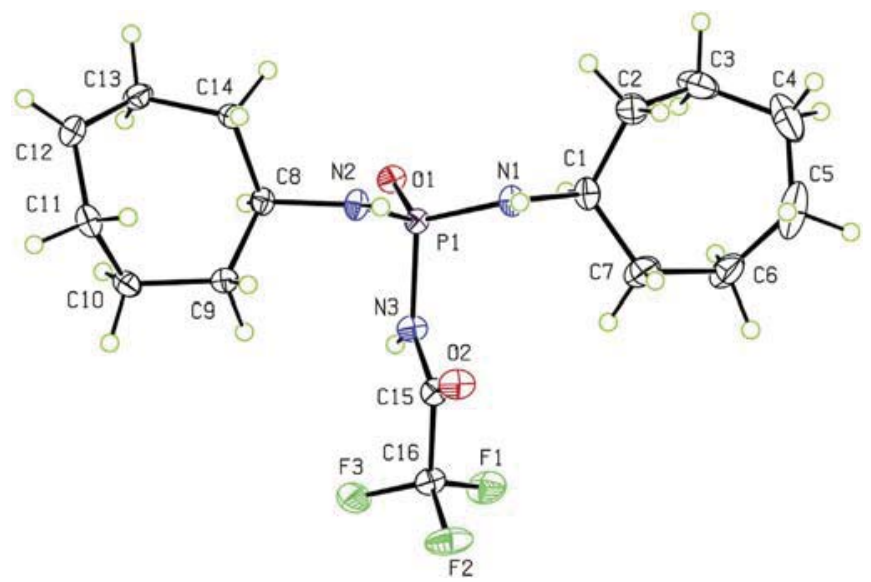

Fig. 2. Displacement ellipsoid plot (30\% probability level) for structure 2, with atom-numbering scheme.

The $\mathrm{P}$ atom exhibits a distorted tetrahedral $\mathrm{P}[\mathrm{O}][\mathrm{N}]_{3}$ configuration with bond angles at the $\mathrm{P}$ atom position (structure $\mathbf{1}$ ), of 103.31 $(9)^{\circ}[\mathrm{N} 2-\mathrm{P} 1-\mathrm{N} 3]$ and $116.06(9)^{\circ}$ [N2-P1-O1]. The $\mathrm{P}-\mathrm{N}_{\mathrm{CP}}$ bond is longer than the two P- $\mathrm{N}_{\mathrm{P}}$ bonds (for 1, 1.698 (17) $\AA$, 1.618 (18) Å and 1.618 (16) $\AA$, respectively) [ $\mathrm{N}_{\mathrm{CP}}$ denotes the nitrogen atom of the $\mathrm{C}(\mathrm{O}) \mathrm{NHP}(\mathrm{O})$ part and $\mathrm{N}_{\mathrm{P}}$ introduces the two other nitrogen atoms bonded to phosphorus]. The longer $\mathrm{P}-\mathrm{N}_{\mathrm{CP}}$ distance is a result of the electron delocalization from the $\mathrm{N}_{\mathrm{CP}}$ lone electron pair towards the $\mathrm{C}=\mathrm{O} \pi$ system, which reduces the interaction of $\mathrm{N}_{C P}$ with the $\mathrm{P}=\mathrm{O}$ system. On the other hand, the $\mathrm{C}-\mathrm{N}_{\mathrm{CP}}$ bond length is shorter than the other $\mathrm{C}-\mathrm{N}$ bond lengths in the molecule $\left(\mathrm{C}-\mathrm{N}_{\mathrm{CP}}=1.353\right.$ (2) $\AA$, $\mathrm{C}-\mathrm{N}_{\mathrm{P}}=1.468$ (3) $\AA$ and 1.428 (4) $\AA$ ). The $\mathrm{P}=\mathrm{O}$ bond length in 1 $(1.475(13) \AA)$ is longer than the normal $\mathrm{P}=\mathrm{O}$ bond length $(1.45 \AA) .{ }^{33}$

The environment of the nitrogen atoms in all structures is practically planar; the exception being the environment of the N9 atom of structure 4 with a bond-angle sum of $351.7(14)^{\circ}$. The positions of three atoms connected to the nitrogen N9 propose an anti-orientation of the lone electron pair (LEP) with respect to the $\mathrm{P}=\mathrm{O}$ group.

Structures 1 and $\mathbf{2}$ include nitrogen atoms within a $(\mathrm{P}) \mathrm{N}(\mathrm{H})(\mathrm{C})$ environment, while there are two nitrogen atoms in each of the

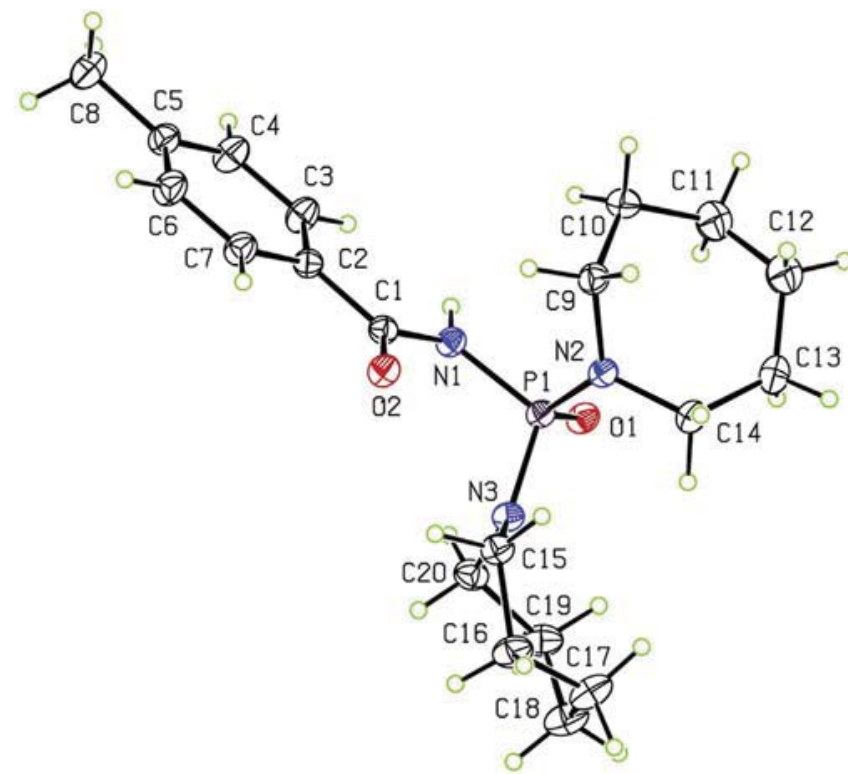

Fig. 3. Displacement ellipsoid plot (30\% probability level) for structure 3, with atom-numbering scheme.

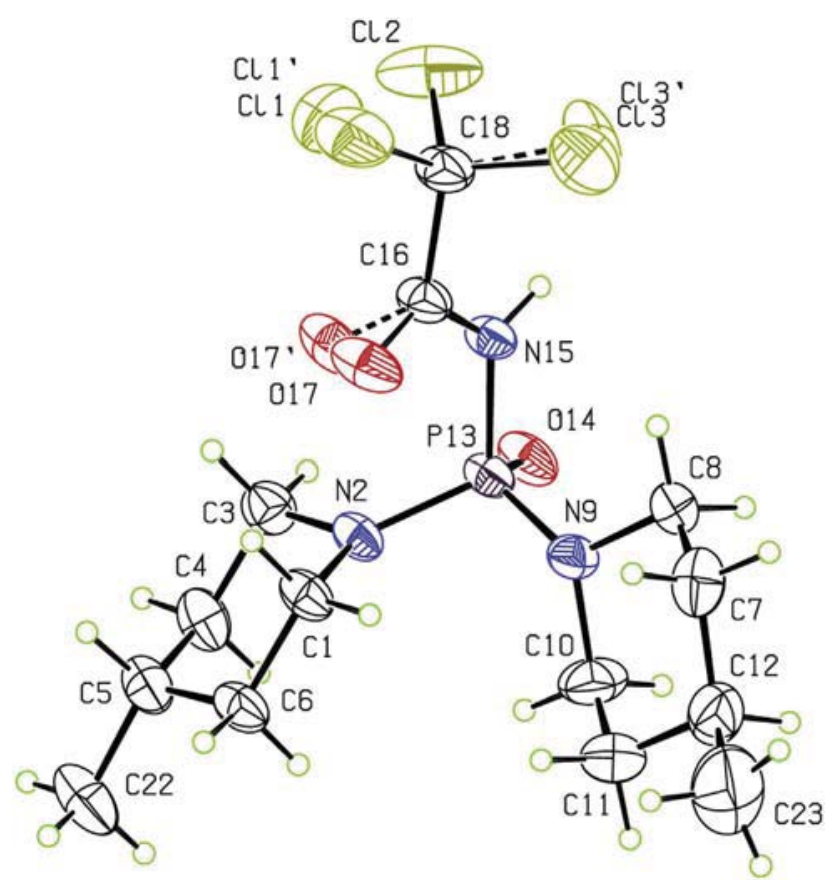

Fig. 4. Displacement ellipsoid plot (30\% probability level) for structure $\mathbf{4}$, with atom-numbering scheme. Dashed lines indicate the minor-disorder component.

structures 3 to $\mathbf{6}$ with a $(\mathrm{P}) \mathrm{N}(\mathrm{C})(\mathrm{C})$ environment. For such a nitrogen atom in structures $\mathbf{4}$ and $\mathbf{5}$ within a cyclo- "C5N" rings, two $\mathrm{P}-\mathrm{N}-\mathrm{C}$ angles are clearly larger than the related $\mathrm{C}-\mathrm{N}-\mathrm{C}$ angle. For example in $4, \mathrm{P} 13-\mathrm{N} 2-\mathrm{C} 3=119.70(15)^{\circ}, \mathrm{P} 13-\mathrm{N} 2-\mathrm{C} 1=125.54(16)^{\circ}$ and $\mathrm{C} 1-\mathrm{N} 2-\mathrm{C} 3=112.82(18)^{\circ}$. Structure 6, with a $(\mathrm{P}) \mathrm{N}\left(\mathrm{CH}_{3}\right)\left(\mathrm{C}_{6} \mathrm{H}_{11}\right)$ fragment, has a $\mathrm{C}-\mathrm{N}-\mathrm{C}$ angle $\left(117.1(2)^{\circ}\right)$ that is larger than one of the $\mathrm{P}-\mathrm{N}-\mathrm{C}$ angles $\left(115.57(17)^{\circ}\right)$, due to the bulk effect of $\mathrm{CH}_{3}$ and $\mathrm{C}_{6} \mathrm{H}_{11}$ groups. Moreover, a similar status is happened in structure $\mathbf{3}$, due to relatively inherent large angle in the seven-membered ring.

As was noted earlier, ${ }^{34}$ the $\mathrm{N}$-atoms bonded to $\mathrm{P}=\mathrm{O}$ in $[R C(\mathrm{O})$ $\mathrm{NH}] \mathrm{P}(\mathrm{O})\left[\mathrm{N} R^{1} R^{2}\right]_{2}$ phosphoric triamides $\left(R^{1} \neq \mathrm{H}, R^{2}=\mathrm{H}\right.$ or $\left.\neq \mathrm{H}\right)$ do 


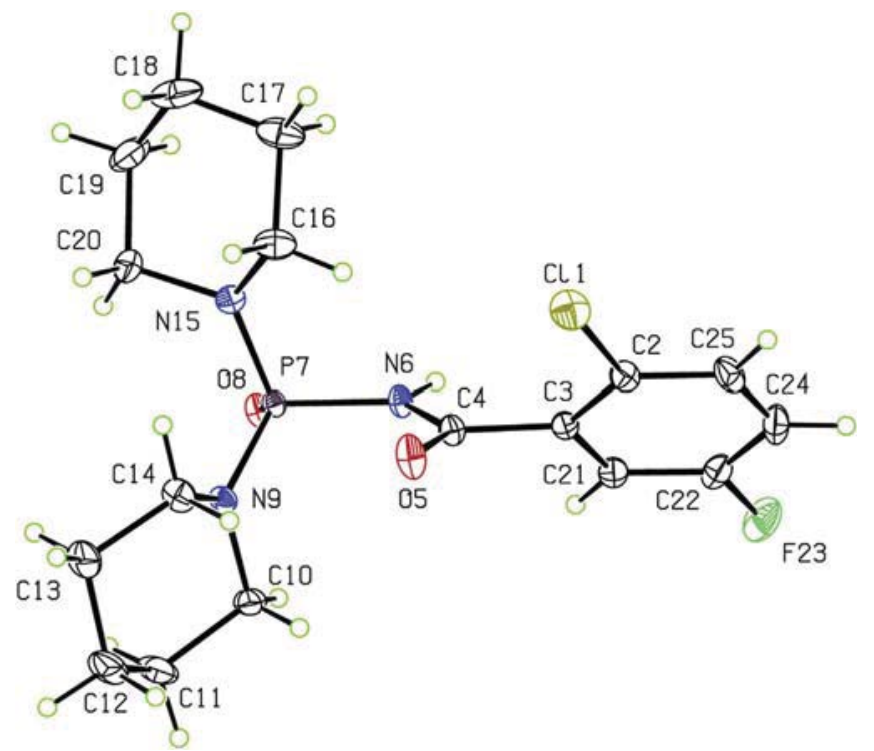

Fig. 5. Displacement ellipsoid plot (30\% probability level) for structure 5, with atom-numbering scheme.

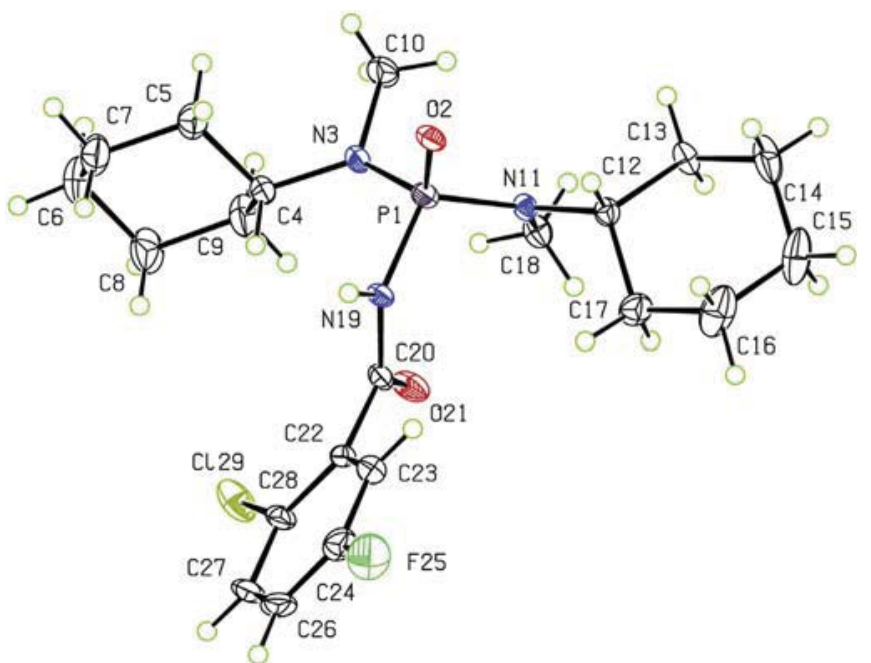

Fig. 6. Displacement ellipsoid plot (30\% probability level) for structure 6, with atom-numbering scheme.

not take part in hydrogen bonding as an acceptor because of their weak Lewis base character. Accordingly, compounds $\mathbf{1}$ and $\mathbf{2}$ contain two hydrogen bond acceptor centers ( $\mathrm{O}$ atoms) and three hydrogen bond donor sites ( $\mathrm{N}$ atoms), while compounds $\mathbf{3}, \mathbf{4}, 5$ and $\mathbf{6}$ can be described as a two-hydrogen-bond-acceptor/onehydrogen-bond-donor model.

In the crystal packing of $\mathbf{1}$, the $\mathrm{N}_{\mathrm{CP}}-\mathrm{H} \cdots \mathrm{O}=\mathrm{P}$ hydrogen bonds and the $\left(\mathrm{N}_{\mathrm{P}}-\mathrm{H} \cdots\right)_{2} \mathrm{O}=\mathrm{C}$ groups respectively form $R_{2}^{2}(8)$ and fused $R_{2}^{1}(6) / R_{2}^{2}(12)$ ring motifs, which propagate into a linear arrangement along the $a$ axis (Fig. 7); for graph-set notation, see Bernstein et al. $^{35}$

Structure 2, with a similar $(\mathrm{C}(\mathrm{O}) \mathrm{NH}) \mathrm{P}(\mathrm{O})(\mathrm{NHC})_{2}$ skeleton as in $\mathbf{1}$, has a different hydrogen bond pattern, where $\left(\mathrm{N}_{\mathrm{P}}-\mathrm{H} \cdots\right)_{2} \mathrm{O}=\mathrm{P}$ and $\mathrm{N}_{\mathrm{CP}}-\mathrm{H} \cdots \mathrm{O}=\mathrm{C}$ hydrogen bonds take part in fused $R_{2}^{1}(6)$ and $R_{2}^{2}(10)$ ring motifs (see Fig. 8), extended into a linear arrangement along the $b$ axis.

A Cambridge Structural Database (CSD, Version 5.37, May $2016)^{36}$ analysis shows that the $R_{2}^{2}(10)$ hydrogen bond motif is less
Table 3

Selected bond distances $(\AA)$ in compounds $\mathbf{1}-\mathbf{6}$.

\begin{tabular}{llll}
\hline Compound 1 & & & \\
\hline N1-P1 & $1.698(17)$ & N1-C1 & $1.353(2)$ \\
N2-P1 & $1.618(18)$ & N2-C9A & $1.428(4)$ \\
N3-P1 & $1.618(16)$ & N3-C16 & $1.468(3)$ \\
O1-P1 & $1.475(13)$ & & \\
Compound 2 & & & \\
N3-P1 & $1.726(15)$ & N1-C1 & $1.471(2)$ \\
N2-P1 & $1.609(15)$ & N2-C8 & $1.474(2)$ \\
N1-P1 & $1.612(15)$ & N3-C15 & $1.343(2)$ \\
O1-P1 & $1.478(13)$ & & \\
Compound 3 & & & \\
N1-P1 & $1.683(16)$ & N1-C1 & $1.368(2)$ \\
N2-P1 & $1.632(17)$ & N2-C9 & $1.474(2)$ \\
N3-P1 & $1.636(17)$ & N2-C14 & $1.472(3)$ \\
O1-P1 & $1.480(14)$ & N3-C15 & $1.466(2)$ \\
Compound 4 & & & \\
N2-P13 & $1.625(18)$ & N2-C1 & $1.474(3)$ \\
N9-P13 & $1.634(2)$ & N2-C3 & $1.457(4)$ \\
N15-P13 & $1.700(18)$ & N9-C8 & $1.462(3)$ \\
O14-P13 & $1.471(16)$ & N9-C10 & $1.467(3)$ \\
Compound 5 & & & \\
N6-P7 & $1.6890(15)$ & N6-C4 & $1.368(2)$ \\
N9-P7 & $1.6319(15)$ & N15-C16 & $1.467(3)$ \\
O8-P7 & $1.4795(13)$ & N15-C20 & $1.470(3)$ \\
C4-O5 & $1.216(2)$ & N9-C10 & $1.470(2)$ \\
Compound 6 & & & \\
N3-P1 & $1.643(2)$ & N3-C4 & $1.477(3)$ \\
N11-P1 & $1.636(2)$ & N11-C12 & $1.476(3)$ \\
N19-P1 & $1.689(2)$ & N11-C18 & $1.468(3)$ \\
O2-P1 & $1.4894(18)$ & N19-C20 & $1.368(3)$ \\
N3-C10 & $1.467(3)$ & & \\
\hline & & & \\
\hline
\end{tabular}

common than the more usual $R_{2}^{2}(8)$ and $R_{2}^{2}(12)$ motifs in the structures of $R \mathrm{C}(\mathrm{O}) \mathrm{NHP}(\mathrm{O})\left[\mathrm{NH}^{1}\right]_{2}$ phosphoric triamides $\left(R^{1} \neq \mathrm{H}\right)$. From 51 deposited $R \mathrm{C}(\mathrm{O}) \mathrm{NHP}(\mathrm{O})\left[\mathrm{NH}^{1}\right]_{2}$ structures, 35 include a $R_{2}^{2}(8)$ motif, accompanied by a $R_{2}^{2}(12)$ motif in 27 structures. When these two motifs simultaneously exist, they are alternatively arranged in the crystal packing. The $R_{2}^{2}(10)$ motif appears in 16 structures. It should be noted that the $R_{2}^{2}(8)$ and $R_{2}^{2}(12)$ motifs are constituted via two $\mathrm{N}_{\mathrm{CP}}-\mathrm{H} \cdots \mathrm{O}=\mathrm{P}$ and two $\mathrm{N}_{\mathrm{P}}-\mathrm{H} \cdots \mathrm{O}=\mathrm{C}$ hydrogen bonds, respectively, while in the $R_{2}^{2}(10)$ motif both carbonyl and phosphoryl groups are involved, and all of the following combinations are found in the CSD for generating this motif: $\mathrm{N}_{\mathrm{P}}-\mathrm{H} \ldots \mathrm{O}=$ $\mathrm{C} / \mathrm{N}_{\mathrm{P}}-\mathrm{H} \ldots \mathrm{O}=\mathrm{P}, \quad \mathrm{N}_{\mathrm{CP}}-\mathrm{H} \ldots \mathrm{O}=\mathrm{C} / \mathrm{N}_{\mathrm{P}}-\mathrm{H} \ldots \mathrm{O}=\mathrm{P}$ or $\mathrm{N}_{\mathrm{P}}-\mathrm{H} \ldots \mathrm{O}=\mathrm{C} /$ $\mathrm{N}_{\mathrm{CP}}-\mathrm{H} \ldots \mathrm{O}=\mathrm{P}$.

The structures 3, 4, 5 and $\mathbf{6}$ have the same generic $[R \mathrm{C}(\mathrm{O}) \mathrm{NH}]$ $\mathrm{P}(\mathrm{O})\left[\mathrm{N} R^{1} R^{2}\right]_{2}\left(R^{1} \& R^{2} \neq \mathrm{H}\right)$ formula and in all of these structures the $\mathrm{P}=\mathrm{O}$ group takes part in the hydrogen bond pattern. These four structures can thus be described as centrosymmetric dimers built from pairs of $\mathrm{N}_{\mathrm{CP}}-\mathrm{H} \cdots \mathrm{O}=\mathrm{P}$ hydrogen bonds with $R_{2}^{2}(8)$ ring motifs (Figs. 9-12).

\subsection{Puckering behaviors of new structures}

In this section, a puckering analysis has been applied to the sixand seven-membered aliphatic rings in the six new structures with the $\mathrm{N}$ atom in an exocyclic position $(\mathbf{1}, \mathbf{2}$ and $\mathbf{6})$ and the $\mathrm{N}$ atom inside the rings $(3,4$ and 5$)$. It should be noted that the structures 1 and $\mathbf{2}$ are the first $\mathrm{C}(\mathrm{O}) \mathrm{NHP}(\mathrm{O})$-based phosphoric triamides with an $\mathrm{NHC}_{7} \mathrm{H}_{13}$ group, studied by single crystal X-ray diffraction.

Table 6 summarizes the theoretical puckering parameters of different conformations in six- and seven-membered rings, whereas Table 7 lists the puckering parameters as obtained for the six compounds obtained in this study.

In structure 1, the ordered $\mathrm{C} 16 / \mathrm{C} 17 / \mathrm{C} 18 / \mathrm{C} 19 / \mathrm{C} 20 / \mathrm{C} 21 / \mathrm{C} 22$ ring displays a close-to-nearly chair conformation, whereas the two 
Table 4

Selected bond angles $\left({ }^{\circ}\right)$ in compounds $1-6$.

\begin{tabular}{|c|c|c|c|}
\hline \multicolumn{4}{|l|}{ Compound $\mathbf{1}$} \\
\hline $\mathrm{O} 1-\mathrm{P} 1-\mathrm{N} 1$ & $105.20(8)$ & $\mathrm{N} 2-\mathrm{P} 1-\mathrm{N} 3$ & $103.31(9)$ \\
\hline $\mathrm{O} 1-\mathrm{P} 1-\mathrm{N} 2$ & $116.06(9)$ & $\mathrm{C} 9 \mathrm{~B}-\mathrm{N} 2-\mathrm{P} 1$ & $124.4(3)$ \\
\hline $\mathrm{O} 1-\mathrm{P} 1-\mathrm{N} 3$ & $113.81(9)$ & $\mathrm{C} 9 \mathrm{~A}-\mathrm{N} 2-\mathrm{P} 1$ & $120.5(2)$ \\
\hline $\mathrm{N} 2-\mathrm{P} 1-\mathrm{N} 1$ & $108.46(9)$ & $\mathrm{C} 16-\mathrm{N} 3-\mathrm{P} 1$ & $123.67(13)$ \\
\hline N3-P1-N1 & $109.94(8)$ & & \\
\hline \multicolumn{4}{|l|}{ Compound $\mathbf{2}$} \\
\hline $\mathrm{O} 1-\mathrm{P} 1-\mathrm{N} 1$ & $116.50(8)$ & $\mathrm{N} 2-\mathrm{P} 1-\mathrm{N} 3$ & $108.83(8)$ \\
\hline $\mathrm{O} 1-\mathrm{P} 1-\mathrm{N} 2$ & $116.70(8)$ & $\mathrm{C} 1-\mathrm{N} 1-\mathrm{P} 1$ & $123.74(12)$ \\
\hline $\mathrm{O} 1-\mathrm{P} 1-\mathrm{N} 3$ & $102.39(7)$ & $\mathrm{C} 8-\mathrm{N} 2-\mathrm{P} 1$ & $124.02(12)$ \\
\hline $\mathrm{N} 2-\mathrm{P} 1-\mathrm{N} 1$ & $103.98(8)$ & $\mathrm{C} 15-\mathrm{N} 3-\mathrm{P} 1$ & $124.05(12)$ \\
\hline $\mathrm{N} 1-\mathrm{P} 1-\mathrm{N} 3$ & $108.11(8)$ & & \\
\hline \multicolumn{4}{|l|}{ Compound $\mathbf{3}$} \\
\hline $\mathrm{O} 1-\mathrm{P} 1-\mathrm{N} 1$ & $105.25(8)$ & $\mathrm{C} 9-\mathrm{N} 2-\mathrm{P} 1$ & $123.52(13)$ \\
\hline $\mathrm{O} 1-\mathrm{P} 1-\mathrm{N} 2$ & $117.28(9)$ & $\mathrm{C} 14-\mathrm{N} 2-\mathrm{P} 1$ & $118.97(14)$ \\
\hline $\mathrm{O} 1-\mathrm{P} 1-\mathrm{N} 3$ & $109.17(8)$ & $\mathrm{C} 15-\mathrm{N} 3-\mathrm{P} 1$ & $125.52(13)$ \\
\hline $\mathrm{N} 2-\mathrm{P} 1-\mathrm{N} 1$ & $105.23(8)$ & C20-N3-P1 & $115.64(13)$ \\
\hline N3-P1-N1 & $111.55(8)$ & $\mathrm{C} 9-\mathrm{N} 2-\mathrm{C} 14$ & $114.50(16)$ \\
\hline $\mathrm{N} 2-\mathrm{P} 1-\mathrm{N} 3$ & $107.38(8)$ & $\mathrm{C} 15-\mathrm{N} 3-\mathrm{C} 20$ & $117.86(16)$ \\
\hline $\mathrm{C} 1-\mathrm{N} 1-\mathrm{P} 1$ & $126.17(14)$ & & \\
\hline \multicolumn{4}{|l|}{ Compound 4} \\
\hline $\mathrm{O} 14-\mathrm{P} 13-\mathrm{N} 2$ & $111.69(10)$ & $\mathrm{C} 1-\mathrm{N} 2-\mathrm{P} 13$ & $125.54(16)$ \\
\hline O14-P13-N9 & $117.99(11)$ & $\mathrm{C} 8-\mathrm{N} 9-\mathrm{C} 10$ & $111.8(2)$ \\
\hline O14-P13-N15 & $106.23(9)$ & C8-N9-P13 & $123.01(17)$ \\
\hline N2-P13-N15 & $111.60(10)$ & C10-N9-P13 & 116.89 (17) \\
\hline N9-P13-N15 & $104.13(10)$ & C16-N15-P13 & $127.12(15)$ \\
\hline N2-P13-N9 & $105.02(10)$ & $\mathrm{C} 3-\mathrm{N} 2-\mathrm{C} 1$ & $112.82(18)$ \\
\hline $\mathrm{C} 3-\mathrm{N} 2-\mathrm{P} 13$ & $119.70(15)$ & $\mathrm{C} 8-\mathrm{N} 9-\mathrm{C} 10$ & $111.8(2)$ \\
\hline \multicolumn{4}{|l|}{ Compound $\mathbf{5}$} \\
\hline O8-P7-N6 & $106.59(8)$ & C16-N15-P7 & $126.24(15)$ \\
\hline O8-P7-N9 & $111.30(8)$ & $\mathrm{C} 20-\mathrm{N} 15-\mathrm{P} 7$ & $118.78(14)$ \\
\hline O8-P7-N15 & $113.75(9)$ & C10-N9-P7 & $118.82(12)$ \\
\hline N6-P7-N9 & $110.46(8)$ & $\mathrm{C} 16-\mathrm{N} 15-\mathrm{C} 20$ & $113.84(17)$ \\
\hline N6-P7-N15 & $105.94(8)$ & C10-N9-C14 & $113.54(15)$ \\
\hline N9-P7-N15 & $108.64(8)$ & & \\
\hline \multicolumn{4}{|l|}{ Compound 6} \\
\hline $\mathrm{O} 2-\mathrm{P} 1-\mathrm{N} 3$ & $117.07(11)$ & $\mathrm{P} 1-\mathrm{N} 3-\mathrm{C} 10$ & $115.57(17)$ \\
\hline $\mathrm{O} 2-\mathrm{P} 1-\mathrm{N} 11$ & $111.00(10)$ & $\mathrm{P} 1-\mathrm{N} 19-\mathrm{C} 20$ & $126.92(17)$ \\
\hline O2-P1-N19 & $104.97(10)$ & $\mathrm{P} 1-\mathrm{N} 11-\mathrm{C} 12$ & $119.13(15)$ \\
\hline N3-P1-N11 & $105.22(11)$ & P1-N11-C18 & $123.31(16)$ \\
\hline N3-P1-N19 & $105.95(10)$ & C4-N3-C10 & $117.1(2)$ \\
\hline N11-P1-N19 & $112.72(10)$ & $\mathrm{C} 12-\mathrm{N} 11-\mathrm{C} 18$ & $116.50(18)$ \\
\hline
\end{tabular}

components of the disordered ring display both a twist-chair conformation.

The cyclo- "C7" rings in compound 2 also adopt a twist-chair conformation, while the cyclo- "C6N" rings in compound $\mathbf{3}$ have a twist-sofa conformation.

The cyclo- "C5N" six-membered rings in compounds $\mathbf{4}$ and $\mathbf{5}$ adopt the nearly-chair conformation and a similar nearly-chair conformation is observed for the " $\mathrm{C6}$ " rings in compound 6 . In the new structures with aliphatic six-membered rings, the largest deviation of the $\theta$ puckering parameter from the ideal chair value of $0^{\circ} / 180^{\circ}$ is found in the 4-methyl-piperidin-yl group in structure $4\left(4.4^{\circ}\right)$. The sequence of deviation from the ideal chair value in six- membered ring groups is as follows: $\mathrm{NC}_{5} \mathrm{H}_{9}-4-\mathrm{CH}_{3}>\mathrm{N}\left(\mathrm{CH}_{3}\right)\left(\mathrm{C}_{6} \mathrm{H}_{11}\right)>\mathrm{NC}_{5} \mathrm{H}_{10}$.

An alternative way to look at the deviations from ideal geometries is to calculate the mean values of the $\mathrm{C}-\mathrm{C}-\mathrm{C}$ or $\mathrm{C}-\mathrm{N}-\mathrm{C}$ angles within the rings. The results show that the $\mathrm{C}-\mathrm{C}-\mathrm{C}$ angles in the seven-membered rings are slightly larger than those in the sixmembered rings. As an example, the angles $\mathrm{C} 17-\mathrm{C} 16-\mathrm{C} 22=114.7$ $(2)^{\circ}$ in $\mathbf{1} \& \mathrm{C} 7-\mathrm{C} 1-\mathrm{C} 2=115.65(17)^{\circ}$ in $\mathbf{2}$ are significantly larger than the angles $\mathrm{C} 9-\mathrm{C} 4-\mathrm{C} 5=111.5(2)^{\circ} \& \mathrm{C} 17-\mathrm{C} 12-\mathrm{C} 13=110.5(2)^{\circ}$ in 6 . The average $\mathrm{C}-\mathrm{C}-\mathrm{C}$ angle in all compounds including a cycloheptyl group $\left(115.4(11)^{\circ}\right)$ is about $4^{\circ}$ more than the average angle in the compounds bearing a cyclohexyl group $\left(111.0(2)^{\circ}\right)$.

The $\mathrm{C}-\mathrm{N}-\mathrm{C}$ angles in both six- and seven-membered rings are slightly larger than the $\mathrm{C}-\mathrm{C}-\mathrm{C}$ angles in the same rings by about $1^{\circ}-2^{\circ}$. For example, the $\mathrm{C} 20-\mathrm{N} 3-\mathrm{C} 15$ angle is $117.86(16)^{\circ}$ in $\mathbf{3}$ (seven-membered) and the C10-N9-C14 angle is $113.54(15)^{\circ}$ in $\mathbf{5}$ (six-membered).

For the reason on why a nitrogen atom shows an angle $(\mathrm{C}-\mathrm{N}-\mathrm{C})$ more than the $\mathrm{C}-\mathrm{C}-\mathrm{C}$ angle in both six- and seven-membered rings, we note that the analysis of bond-angle sum at the nitrogen atom bonded to phosphorus proposes a tendency to the $s p^{2}$ hybridization with the angle naturally more than the $s p^{3}$ angle, however due to the presence of one $\mathrm{P}$ and two $\mathrm{C}$ atoms around the $\mathrm{N}$ atom, the three angles at the $\mathrm{N}$ atom are different, with the two $\mathrm{P}-\mathrm{N}-\mathrm{C}$ angles usually more than the $\mathrm{C}-\mathrm{N}-\mathrm{C}$ angle. ${ }^{37} \mathrm{~A}$ comparison of $\mathrm{C}-\mathrm{N}-\mathrm{C}$ angles in the six- and seven-membered ring systems with an exocyclic $\mathrm{C}-\mathrm{N}-\mathrm{C}$ angle shows that the angle out of the ring is more open than the angle of six-membered ring, and close to the one in the seven-membered ring. For example, the exocyclic $\mathrm{C}-\mathrm{N}-\mathrm{C}$ angle in the structure with the CSD refcode ORISUE, ${ }^{38}$ is a few more than $118^{\circ}$.

It can thus be concluded that a saturated $\mathrm{C}$ atom $\left(s p^{3}\right)$ opens the $\mathrm{C}-\mathrm{C}-\mathrm{C}$ angle for self-adaptation in the ring system, while an $\mathrm{N}$ atom $\left(s p^{2}\right)$ contracts the $\mathrm{C}-\mathrm{N}-\mathrm{C}$ angle in this situation. According to the discussion noted, we can conclude the following sequences of angles $(\mathrm{C}-\mathrm{N}-\mathrm{C})_{7 \text {-membered }}>(\mathrm{C}-\mathrm{C}-\mathrm{C})_{7 \text {-membered }}>(\mathrm{C}-\mathrm{N}-\mathrm{C})_{6}$ -

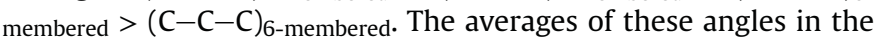
new structures are about $116^{\circ}, 115^{\circ}, 113^{\circ}$ and $111^{\circ}$.

In summary, the preferred conformation in aliphatic sixmembered rings, cyclo- "C6" and "C5N", is nearly-chair but in seven-membered rings, cyclo- "C7" and "C6N" with more flexibility,

Table 5

Hydrogen bonds for compounds $\mathbf{1}-\mathbf{6}\left[\AA ̊\right.$ and $\left.{ }^{\circ}\right]$.

\begin{tabular}{|c|c|c|c|c|c|}
\hline $\mathrm{D}-\mathrm{H} \ldots \mathrm{A}$ & $\mathrm{d}(\mathrm{D}-\mathrm{H})$ & $\mathrm{d}(\mathrm{H} \ldots \mathrm{A})$ & $d(D \ldots A)$ & $\angle(\mathrm{DHA})$ & Symmetry codes \\
\hline \multicolumn{6}{|l|}{ Compound 1} \\
\hline $\mathrm{N} 1-\mathrm{H} 1 N \cdots \mathrm{O} 1^{\mathrm{i}}$ & $0.86(2)$ & $1.99(2)$ & $2.842(2)$ & $170(2)$ & (i) $-x+2,-y,-z+2$ \\
\hline $\mathrm{N} 3-\mathrm{H} 3 N \cdots \mathrm{O} 2$ & $0.84(2)$ & $2.58(2)$ & $2.983(2)$ & $111(2)$ & \\
\hline $\mathrm{N} 3-\mathrm{H} 3 N \cdots \mathrm{O} 2^{\mathrm{ii}}$ & $0.84(2)$ & $2.40(2)$ & $3.104(2)$ & $142(2)$ & (ii) $-x+1,-y,-z+2$ \\
\hline $\mathrm{N} 2-\mathrm{H} 2 \mathrm{~N} \cdots \mathrm{O} 2^{\mathrm{ii}}$ & $0.86(2)$ & $2.26(2)$ & $3.050(2)$ & $154(2)$ & (ii) $-x+1,-y,-z+2$ \\
\hline \multicolumn{6}{|l|}{ Compound $\mathbf{2}$} \\
\hline $\mathrm{N} 1-\mathrm{H} 1 N \cdots \mathrm{O} 1^{\mathrm{i}}$ & $0.86(1)$ & $2.18(1)$ & $2.984(19)$ & $155(2)$ & (i) $x, y+1, z$ \\
\hline $\mathrm{N} 2-\mathrm{H} 2 N \cdots \mathrm{O} 1^{\mathrm{i}}$ & $0.87(1)$ & $2.08(1)$ & $2.906(19)$ & $160(2)$ & (i) $x, y+1, z$ \\
\hline $\mathrm{N} 3-\mathrm{H} 3 N \cdots \mathrm{O} 2^{\mathrm{ii}}$ & $0.87(1)$ & $2.02(1)$ & $2.878(19)$ & $169(2)$ & (ii) $x, y-1, z$ \\
\hline \multicolumn{6}{|l|}{ Compound 3} \\
\hline $\mathrm{N} 1-\mathrm{H} 1 \cdots \mathrm{O} 1^{\mathrm{i}}$ & $0.89(2)$ & $1.94(2)$ & $2.802(2)$ & $164(2)$ & (i) $-x+1,-y+1,-z+1$ \\
\hline \multicolumn{6}{|l|}{ Compound 4} \\
\hline $\mathrm{N} 15-\mathrm{H} 15 \cdots \mathrm{O} 14^{\mathrm{i}}$ & 0.86 & 1.99 & $2.777(2)$ & 152 & (i) $-x+1,-y,-z+1$ \\
\hline \multicolumn{6}{|l|}{ Compound $\mathbf{5}$} \\
\hline $\mathrm{N} 6-\mathrm{H} 61 \cdots 08^{\mathrm{i}}$ & 0.85 & 1.95 & $2.789(4)$ & $171(2)$ & (i) $-x,-y,-z$ \\
\hline \multicolumn{6}{|l|}{ Compound 6} \\
\hline $\mathrm{N} 19-\mathrm{H} 191 \cdots \mathrm{O} 2^{\mathrm{i}}$ & 0.85 & 1.92 & $2.752(5)$ & $166(3)$ & (i) $-x+1,-y+1,-z+1$ \\
\hline
\end{tabular}




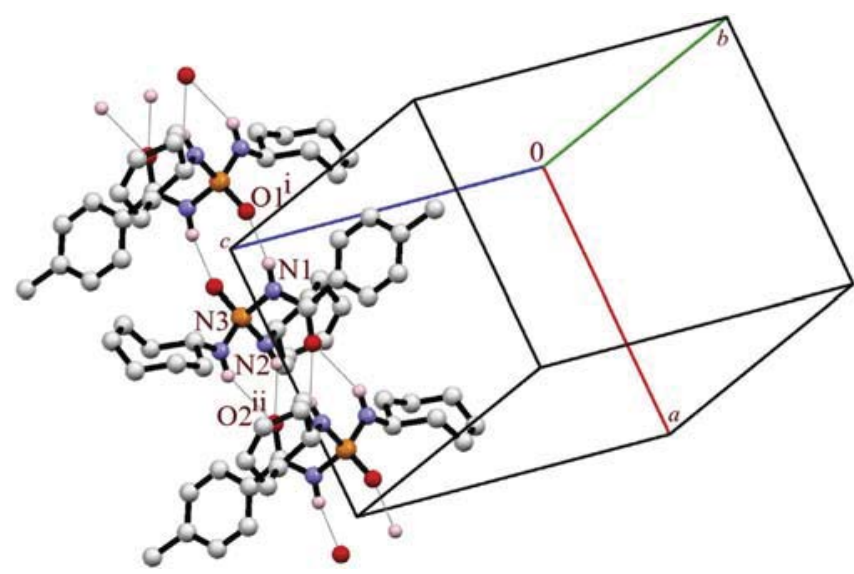

Fig. 7. Part of the crystal packing of $\mathbf{1}$, showing the one-dimensional arrangement built from $\mathrm{N}_{\mathrm{CP}}-\mathrm{H} \cdots \mathrm{O}=\mathrm{P}$ and $(\mathrm{N}-\mathrm{H} \cdots)_{2} \mathrm{O}=\mathrm{C}$ hydrogen bonds. The hydrogen bonds are shown as thin grey lines. $\mathrm{H}$ atoms not involved in hydrogen bonding were omitted for clarity [Symmetry codes: (i) $-x+2,-y,-z+2$; (ii) $-x+1,-y,-z+2$ ].
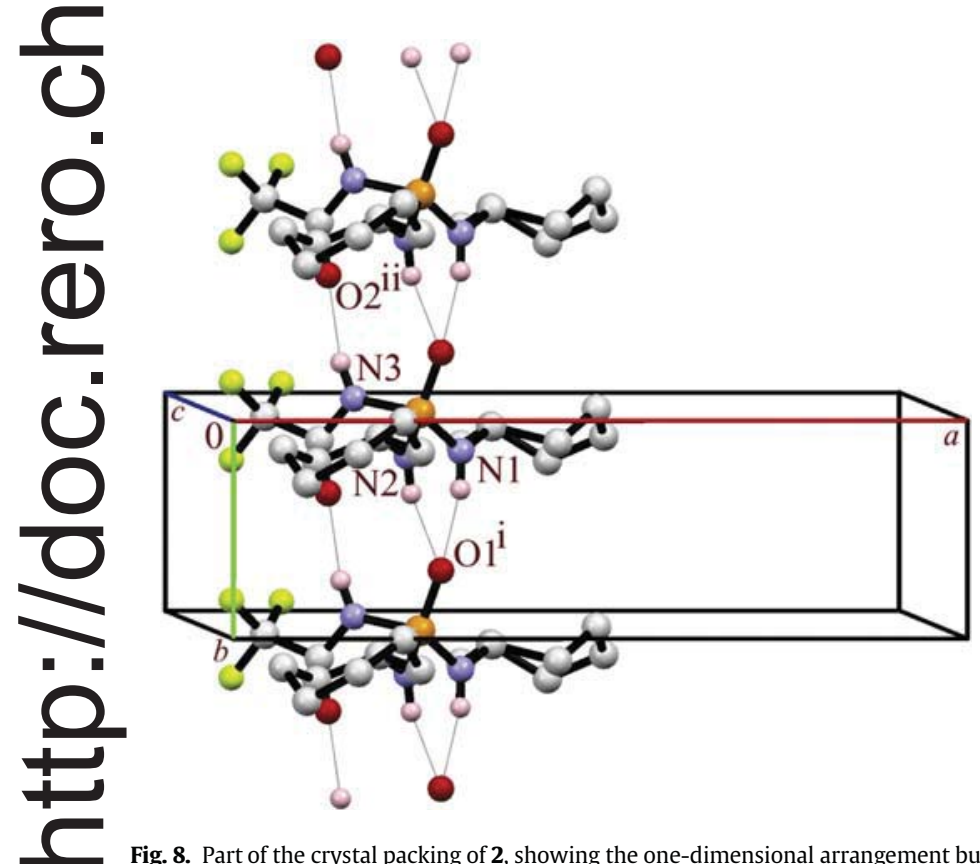

Fig. 8. Part of the crystal packing of $\mathbf{2}$, showing the one-dimensional arrangement built from $(\mathrm{N}-\mathrm{H} \cdots)_{2} \mathrm{O}=\mathrm{P}$ and $\mathrm{N}_{\mathrm{CP}}-\mathrm{H} \cdots \mathrm{O}=\mathrm{C}$ hydrogen bonds. The hydrogen bonds are shown as thin grey lines. $\mathrm{H}$ atoms not involved in hydrogen bonding were omitted for clarity [Symmetry codes: (i) $x, y+1, z$; (ii) $x, y-1, z$ ].

more diverse conformational forms are seen. Indeed, the heteroatom does not cause a harsh change on the conformational properties of the compounds, but it leads to a slightly more open angle. The next section gives a more detailed analysis of $\mathrm{C}-\mathrm{N}-\mathrm{C}$ and $\mathrm{C}-\mathrm{C}-\mathrm{C}$ angles inside the rings with the help of a CSD survey.

\subsection{The $C-N-C$ and $C-C-C$ angles: a survey on the CSD}

In order to complete the analysis of $\mathrm{C}-\mathrm{C}-\mathrm{C}$ and $\mathrm{C}-\mathrm{N}-\mathrm{C}$ angles, we consider here the $\mathrm{C}-\mathrm{N}-\mathrm{C}$ bond angles in ring systems with any size (three to seven) in $[\mathrm{C}(=\mathrm{O}) \mathrm{NH}] \mathrm{P}(=\mathrm{O})[\mathrm{N}(\mathrm{C})(\mathrm{C})]_{2}$-based phosphoric triamides, and also the $\mathrm{C}-\mathrm{N}-\mathrm{C}$ bond angles out of a ring or in acyclic groups. The CSD in version 5.37 (updated in February 2016) was used and compounds with a disorder in the $\mathrm{N}$ or surrounding atoms were omitted. Six compounds with unusual bond

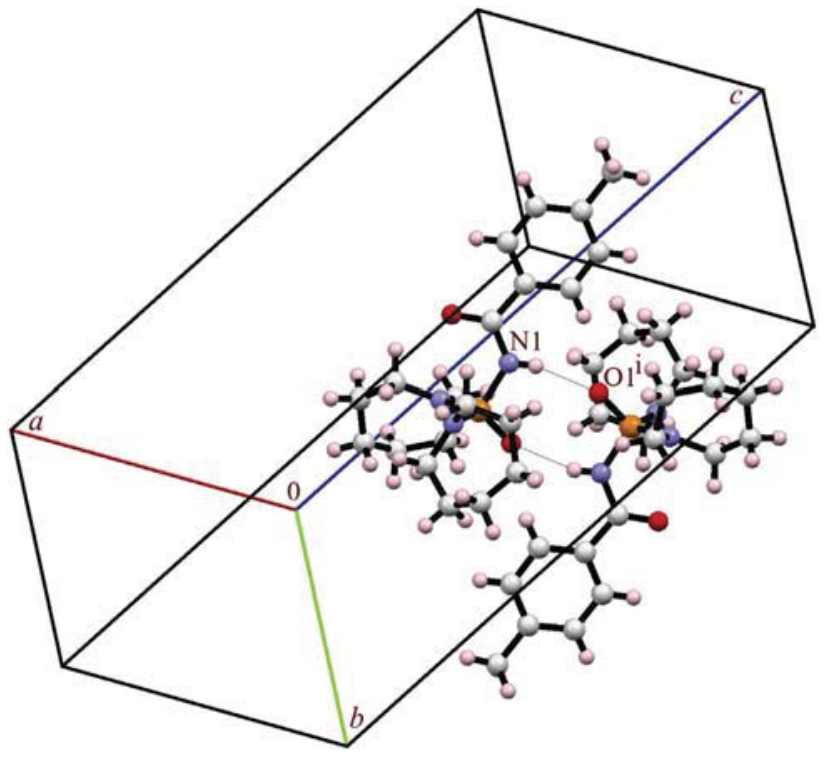

Fig. 9. Part of the crystal structure of $\mathbf{3}$, showing the dimer arrangement built from $\mathrm{N}_{\mathrm{CP}}-\mathrm{H} \cdots \mathrm{O}=\mathrm{P}$ hydrogen bonds (thin grey lines) [Symmetry code: (i) $-x+1,-y+1$, $-z+1]$.

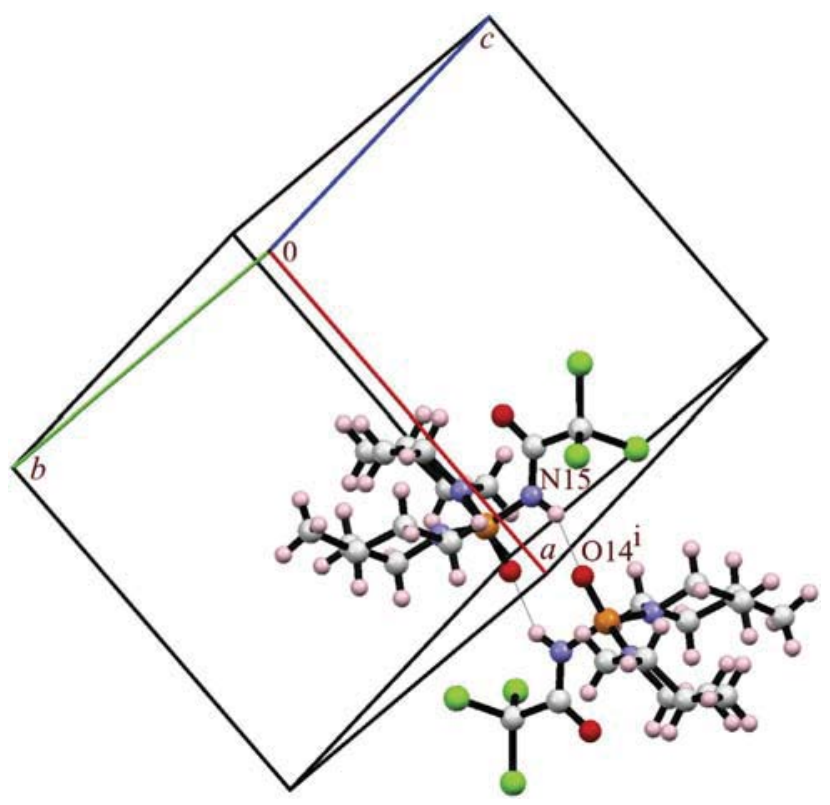

Fig. 10. Part of the crystal structure of $\mathbf{4}$, showing the dimer arrangement built from $\mathrm{N}_{\mathrm{CP}}-\mathrm{H} \cdots \mathrm{O}=\mathrm{P}$ hydrogen bonds (thin grey lines) [Symmetry code: (i) $-x+1,-y,-z+1$ ].

angles were also excluded, leaving a set of 97 structures for this analysis including 213 entries of angles. The results are gathered in Table 8 and the histogram is shown in Fig. 13. In this figure, white columns are related to the $\mathrm{C}-\mathrm{N}-\mathrm{C}$ bond angles out of rings or in acyclic groups. The other columns shown as purple, orange, blue, green and red colors are related to the angles inside the rings of the sizes three, four, five, six and seven, respectively.

The data clearly show that, for most of the studied structures, the internal $\mathrm{C}-\mathrm{N}-\mathrm{C}$ bond angles is the largest for seven-membered rings and gradually decreases to the smallest values for three- 


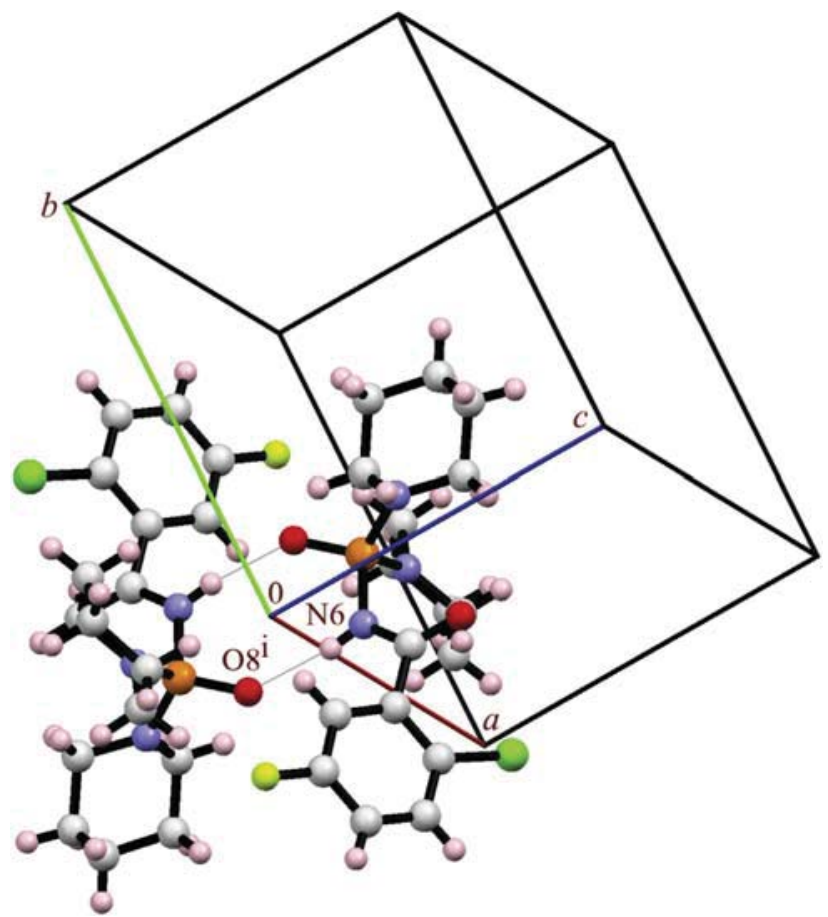

Fig. 11. Part of the crystal structure of $\mathbf{5}$, showing the dimer arrangement formed through $\mathrm{N}_{\mathrm{CP}}-\mathrm{H} \cdots \mathrm{O}=\mathrm{P}$ hydrogen bonds (thin grey lines) [Symmetry code: (i) $-x,-y,-z$ ].

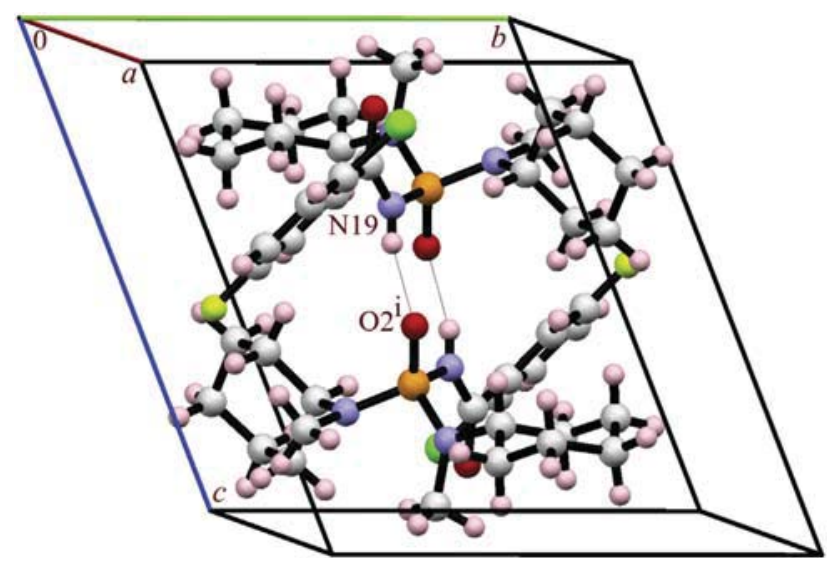

Fig. 12. Part of the crystal structure of $\mathbf{6}$, showing the dimer arrangement formed through $\mathrm{N}_{\mathrm{CP}}-\mathrm{H} \cdots \mathrm{O}=\mathrm{P}$ hydrogen bonds(thin grey lines) [Symmetry code: (i) $\left.-x+1,-y+1,-z+1\right]$. membered rings. The $\mathrm{C}-\mathrm{N}-\mathrm{C}$ bond angles out of a ring stand in the large values, too. The averages of angles in different rings and out of a ring are as follows: $59^{\circ}$ (3-membered), $92^{\circ}$ (4-membered), $110^{\circ}$ (5-membered), $112^{\circ}$ (6-membered), $115^{\circ}$ (acyclic/out of the ring) and $116^{\circ}$ (7-membered).

A similar analysis was performed for $\mathrm{C}-\mathrm{C}-\mathrm{C}$ bond angles in rings containing only carbon atoms in $[\mathrm{C}(=\mathrm{O}) \mathrm{NH}] \mathrm{P}(=\mathrm{O})[\mathrm{N}(\mathrm{C})(\mathrm{C})]_{2^{-}}$ based phosphoric triamides. Only five- and six-membered rings exist in the CSD, besides the seven-membered rings in the new structures $\mathbf{1}$ and $\mathbf{2}$. As the number of hits is low, the histogram is not shown and merely the average values are reported. For a 5membered (cyclo- "C5") ring, 4 hits generated an average angle of $102.52^{\circ}$, while an average of $110.97^{\circ}$ was obtained for 22 hits of $6-$ membered (cyclo- "C6") aliphatic rings. In the new structures with six- and seven-membered rings, we showed that the differences between $\mathrm{C}-\mathrm{C}-\mathrm{C}$ and $\mathrm{C}-\mathrm{N}-\mathrm{C}$ angles are small for rings with the same sizes. This is also valid for the six-membered rings in the CSD; however, the difference between average $\mathrm{C}-\mathrm{C}-\mathrm{C}$ and $\mathrm{C}-\mathrm{N}-\mathrm{C}$ is relatively high in five-membered rings (more than $7^{\circ}$ ).

Three-, four- and seven-membered carbon rings are absent in the CSD, so, to complete this discussion, an analysis was considered for the $\mathrm{C}-\mathrm{C}-\mathrm{C}$ internal bond angles in compounds with cyclo"C3N" and "C6N" aliphatic rings, which yielded an average of $88.04^{\circ}$ (4 hits) and $114.90^{\circ}$ (20 hits), respectively. Naturally, the "C2N" ring does not include any internal $\mathrm{C}-\mathrm{C}-\mathrm{C}$ angle. So, in rings with any sizes from the CSD, the $\mathrm{C}-\mathrm{C}-\mathrm{C}$ angles show a trend to be more contracted than the $\mathrm{C}-\mathrm{N}-\mathrm{C}$ ones.

\subsection{Puckering behavior of $C(O) N H P(O)$-based phosphoric triamides including aliphatic rings: a survey on the CSD}

A survey on the CSD (version 5.37) for the $\mathrm{C}(\mathrm{O}) \mathrm{NHP}(\mathrm{O})$-based phosphoric triamides yielded 57 structures including three-, four, five-, six- and seven-membered aliphatic ring groups. The rings in this family of compounds are mostly of the type "CN" or "CN-1N" for an $\mathrm{N}$-membered ring (" $\mathrm{C}$ " and " $\mathrm{N}$ ": carbon and nitrogen in the ring). There are also two $\mathrm{PC} 2 \mathrm{~N} 2$-based five-membered rings and some PC3N2-based six-membered rings in the CSD.

Since the cyclopropane ring is planar, the question of conformation does not arise. ${ }^{39}$ The puckering parameters for the " $\mathrm{C} 2 \mathrm{~N}$ " rings retrieved from the CSD (10 structures) cannot be defined and just the ring bond distance and torsion angle are reported. There are no three-membered carbon rings in the CSD.

The ring in cyclobutane looks like a squared creased and bent along its diagonal, ${ }^{40}$ similar to what is observed for the only structure with a "C3N" skeleton in the CSD (refcode LAYMII), ${ }^{41}$ where the parameters of $Q$ and torsion angle have been

Table 6

Puckering parameters for different conformations based on Cremer \& Pople (1975) ${ }^{18}$ for 6-membered rings and Boessenkool \& Boeyens $(1980)^{21}$ for 7-membered rings.

\begin{tabular}{lllll}
\hline (A) Six-membered & Conformation & $\boldsymbol{Q}$ & $\boldsymbol{\theta}$ & $\boldsymbol{\varphi}$ \\
\hline 1 & Chair (C) & constant & $0 / 180$ & 0 \\
2 & Boat (B) & constant & 90 & $0 / 60 / 120 / 180 / 240 / 300$ \\
3 & Twist-Boat (TB) & constant & 90 & $30 / 90 / 150 / 210 / 270 / 330$ \\
4 & Half-Chair (HC) & constant & Between (1) and (3) & \\
5 & Half-Boat (HB) & constant & Between (1) and (2) \\
\hline (B) Seven-membered & & $\mathbf{q}_{\mathbf{2}}$ & $\mathbf{q}_{\mathbf{3}}$ \\
\hline 1 & Boat \& Twist-Boat (B \& TB) & 1.15 & 0 \\
2 & Chair (C) & 0.43 & 0.60 \\
3 & Twist-Chair (TC) & 0.52 & 0.61 \\
4 & Boat-Sofa (BS) & 1.08 & 0.30 \\
5 & Sofa (S) & 0.47 & 0.47 \\
6 & Twist-Sofa (TS) & 0.40 & 0.50 \\
\hline
\end{tabular}


Table 7

Puckering parameters for the 7-membered rings of compounds 1-3 and 6-membered rings of compounds 4-6.

\begin{tabular}{|c|c|c|c|c|c|c|}
\hline Compound & 7-membered ring & $\boldsymbol{q}_{2}$ & $\mathbf{q}_{3}$ & $\varphi_{2}$ & $\varphi_{3}$ & $Q_{\mathrm{T}}$ \\
\hline \multirow[t]{3}{*}{1} & $\mathrm{C} 9 \mathrm{~A} / \mathrm{C} 10 \mathrm{~A} / \mathrm{C} 11 \mathrm{~A} / \mathrm{C} 12 \mathrm{~A} / \mathrm{C} 13 \mathrm{~A} / \mathrm{C} 14 \mathrm{~A} / \mathrm{C} 15 \mathrm{~A}$ & $0.505(7)$ & $0.634(6)$ & $43.0(8)$ & $194.3(8)$ & $0.810(8)$ \\
\hline & $\mathrm{C} 9 \mathrm{~B} / \mathrm{C} 10 \mathrm{~B} / \mathrm{C} 11 \mathrm{~B} / \mathrm{C} 12 \mathrm{~B} / \mathrm{C} 13 \mathrm{~B} / \mathrm{C} 14 \mathrm{~B} / \mathrm{C} 15 \mathrm{~B}$ & $0.499(9)$ & $0.685(10)$ & $270.5(11)$ & $271.5(7)$ & $0.847(8)$ \\
\hline & $\mathrm{C} 16 / \mathrm{C} 17 / \mathrm{C} 18 / \mathrm{C} 19 / \mathrm{C} 20 / \mathrm{C} 21 / \mathrm{C} 22$ & $0.434(3)$ & $0.642(3)$ & $333.9(4)$ & $171.3(3)$ & $0.775(3)$ \\
\hline \multirow[t]{2}{*}{2} & $\mathrm{C} 1 / \mathrm{C} 2 / \mathrm{C} 3 / \mathrm{C} 4 / \mathrm{C} 5 / \mathrm{C} 6 / \mathrm{C} 7$ & $0.542(3)$ & $0.637(2)$ & $325.7(3)$ & $168.4(2)$ & $0.837(3)$ \\
\hline & $\mathrm{C} 8 / \mathrm{C} 9 / \mathrm{C} 10 / \mathrm{C} 11 / \mathrm{C} 12 / \mathrm{C} 13 / \mathrm{C} 14$ & $0.529(2)$ & $0.642(2)$ & $36.5(2)$ & $191.82(18)$ & $0.831(2)$ \\
\hline \multirow[t]{3}{*}{3} & $\mathrm{~N} 2 / \mathrm{C} 9 / \mathrm{C} 10 / \mathrm{C} 11 / \mathrm{C} 12 / \mathrm{C} 13 / \mathrm{C} 14$ & $0.552(3)$ & $0.555(2)$ & $242.8(3)$ & $147.0(3)$ & $0.783(3)$ \\
\hline & N3/C15/C16/C17/C18/C19/C20 & $0.534(2)$ & $0.628(2)$ & $161.9(2)$ & $115.3(2)$ & $0.751(4)$ \\
\hline & 6-membered ring & $Q$ & & $\theta$ & & $\varphi$ \\
\hline \multirow[t]{2}{*}{4} & $\mathrm{~N} 2 / \mathrm{C} 3 / \mathrm{C} 4 / \mathrm{C} 5 / \mathrm{C} 6 / \mathrm{C} 1$ & $0.557(3)$ & & $178.7(3)$ & & $153(14)$ \\
\hline & $\mathrm{N} 9 / \mathrm{C} 8 / \mathrm{C} 7 / \mathrm{C} 12 / \mathrm{C} 11 / \mathrm{C} 10$ & $0.548(3)$ & & $4.4(3)$ & & $343(5)$ \\
\hline \multirow[t]{2}{*}{5} & N9/C10/C11/C12/C13/C14 & $0.566(3)$ & & $178.1(13)$ & & $88(7)$ \\
\hline & N15/C16/C17/C18/C19/C20 & $0.570(3)$ & & $0.9(3)$ & & $63(10)$ \\
\hline \multirow[t]{2}{*}{6} & $\mathrm{C} 4 / \mathrm{C} 5 / \mathrm{C} 6 / \mathrm{C} 7 / \mathrm{C} 8 / \mathrm{C} 9$ & $0.573(4)$ & & $177.2(4)$ & & $58(8)$ \\
\hline & $\mathrm{C} 12 / \mathrm{C} 13 / \mathrm{C} 14 / \mathrm{C} 15 / \mathrm{C} 16 / \mathrm{C} 17$ & $0.571(4)$ & & $2.6(4)$ & & $11(8)$ \\
\hline
\end{tabular}

Table 8

The $\mathrm{C}-\mathrm{N}-\mathrm{C}$ angles at the tertiary $\mathrm{N}$ atoms with a $[\mathrm{C}(=\mathrm{O}) \mathrm{NH}]$ $\mathrm{P}(=\mathrm{O})[\mathrm{N}(\mathrm{C})(\mathrm{C})]_{2}$ skeleton.

\begin{tabular}{lll}
\hline $\mathrm{C}-\mathrm{N}-\mathrm{C}$ angle type & $\mathrm{C}-\mathrm{N}-\mathrm{C}$ angle range & Average \\
\hline In acyclic segments & $112-119^{\circ}$ & $115^{\circ}$ \\
In 3-membered rings & $56.5-61.5^{\circ}$ & $59^{\circ}$ \\
In 4-membered rings & $91.5-92.5^{\circ}$ & $92^{\circ}$ \\
In 5-membered rings & $107.5-111.5^{\circ}$ & $110^{\circ}$ \\
In 6-membered rings & $108.5-115.5^{\circ}$ & $112^{\circ}$ \\
In 7-membered rings & $113-118.5^{\circ}$ & $116^{\circ}$ \\
\hline
\end{tabular}

calculated (for example, torsion angles within $8.77^{\circ}-14.90^{\circ}$ for 4 rings of two symmetry independent molecules of LAYMII). Also, conformational studies in some examples including poly-cyclic rings ${ }^{42}$ show that the differences in the dihedral angles of fourmembered rings (within $0^{\circ}$ to above $30^{\circ}$ ), resulting from differing ring systems fused to the cyclobutane, are relatively independent of how the molecule packs in the crystal.

Cyclopentane is non-planar and the two minimum energy geometries are the envelope and the half-chair conformations. ${ }^{43}$ To

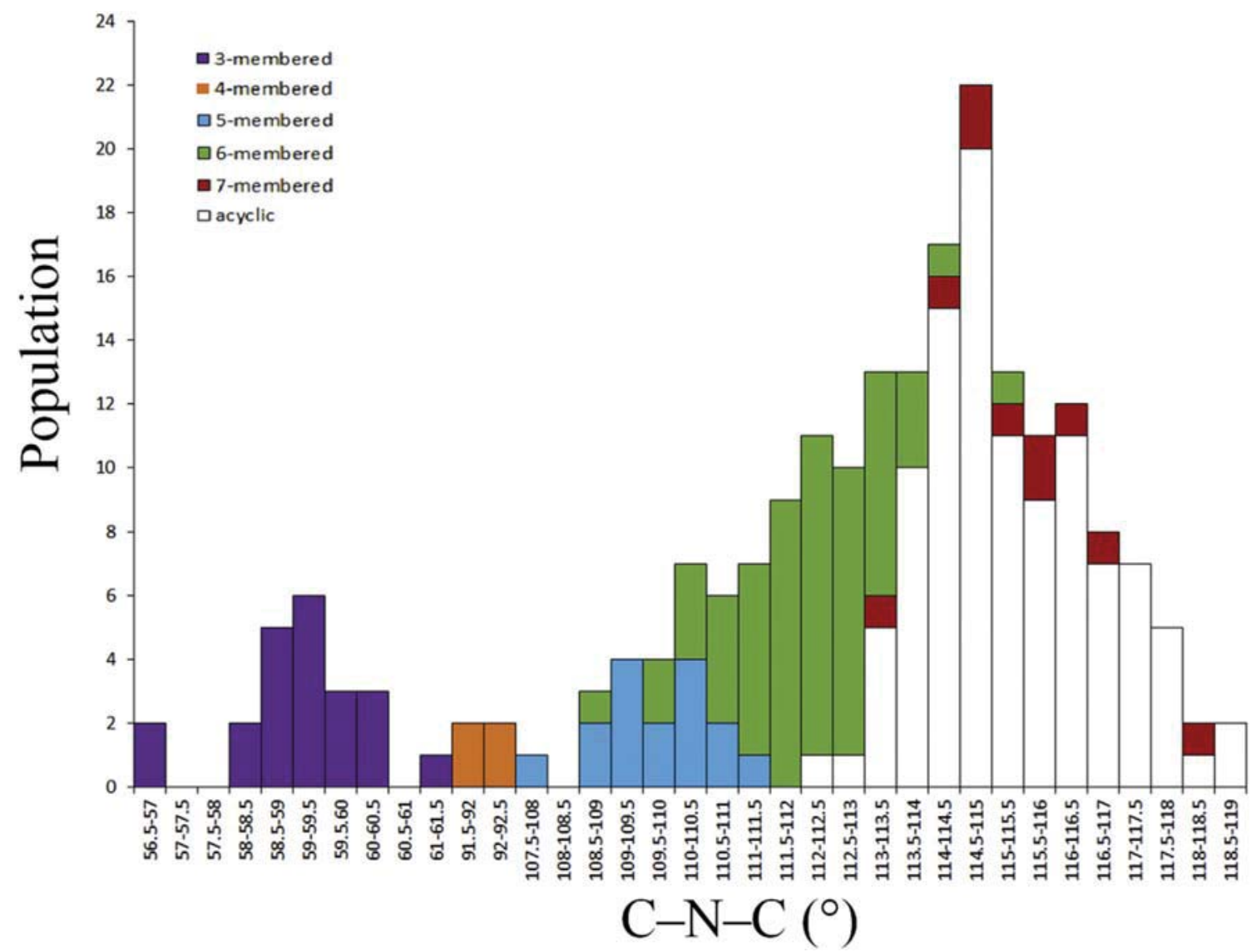

Fig. 13. Histogram of the $\mathrm{C}-\mathrm{N}-\mathrm{C}$ angles at the tertiary $\mathrm{N}$ atoms in compounds with a $[\mathrm{C}(=\mathrm{O}) \mathrm{NH}] \mathrm{P}(=\mathrm{O})[\mathrm{N}(\mathrm{C})(\mathrm{C})]_{2}$ skeleton. White columns are related to acyclic compounds or the compounds with the tertiary $\mathrm{N}$ atom outside the amine ring. Other columns (shown with purple, orange, blue, green and red colors) are related to compounds with $\mathrm{N}$ atom inside the rings (three, four, five, six and seven-membered amine rings, respectively). 
illustrate the conformation of such rings, the puckering parameters $Q$ and $\varphi$ are used. There are 12 structures with five-membered ring parts including 3 "C5", 7 "C4N" and 2 "C2N2P" structures with calculated envelope conformations for the first and a half-chair conformation for the second and third. The difference between the envelope and half-chair conformations is mostly related to the $\varphi$ parameter which is $0^{\circ}$ or $180^{\circ}$ for the envelope conformation, and $90^{\circ}$ or $270^{\circ}$ for the half-chair conformation. An example of a typical "C2N2P" structure is that with refcode DIGHEI ${ }^{44}(Q=0.209(2)$ and $\left.\varphi=112.5(5)^{\circ}\right)$.

A set of 18 structures with a "C6" (6 structures) or "C5N" (12 structures) group was investigated and all of them show a near chair conformation, with a slight deviation from the ideal chair of cyclohexane caused by the bulk phosphorus-containing group in the equatorial position of the ring. For the aliphatic heterocyclic "C3N2P" ring a half-boat conformation was found and, as a typical example, the structure with refcode TENQAG ${ }^{45}$ yielded puckering parameters of $Q=0.510(2), \theta=20.5(2)^{\circ}$ and $\varphi=139.4(7)^{\circ}$, conforming to a half-boat conformation.

As ring size increases, there are progressively more conformations that have to be considered. For cycloheptane, four conformations have been calculated to be particularly stable (boat, chair, twist-boat and twist-chair). ${ }^{46}$ It is necessary to mention that the sofa and twist-sofa conformations have also been observed for such a ring. ${ }^{21}$ As was observed for the new structures reported in this study, seven-membered rings are rather flexible with different conformations observed. This is related to the fact that the crystal structures with seven-membered rings are often disordered. Also, it is possible to have a conformational state not fitting exactly with one of the ideal conformations noted, and with puckering parameters near to two or more conformations. There is no report of an eight-membered ring in this family.

\subsection{Parameters influencing the conformational behavior}

Over the past decade, the conformations of six-membered ring phosphates have been studied and the stereoelectronic, steric and packing effects influencing on the conformations were considered. ${ }^{29,30}$ Here we study these factors in $\mathrm{C}(\mathrm{O}) \mathrm{NHP}(\mathrm{O})$-based phosphoric triamides.

2.5.1. Stereoelectronic effect and the perturbation caused by the presence of a heteroatom in a ring

"Stereoelectronic" mostly refers to a specific stereochemistry and/or conformation induced by electronic factors. ${ }^{29}$ As an example, we refer to the "anomeric effect" in $\left(\mathrm{C}_{6} \mathrm{H}_{5} \mathrm{O}\right) \mathrm{P}(\mathrm{O})\left[(\mathrm{O})_{2} R\right]$ compounds, where $R$ has a $\mathrm{C}(\mathrm{Ar})-\mathrm{C}-\mathrm{C}$ skeleton. It was proposed that this effect causes the spontaneous cleavage of cyclic phosph(on)ate prodrugs. ${ }^{30}$ The isomerization is favored by a natural hyperconjugation between the non-bonding orbital of the oxygen atom of the ring and $\sigma^{*}$ of the exocyclic $\mathrm{P}-\mathrm{O}$. Such an effect was also reported for cyclic-phosphoric triamides including a six-membered diazaphosphorinane ring. In these structures, the $n$ to $\sigma^{*}$ overlap of non-bonding electrons located on the endocyclic nitrogen atoms was with the anti-bonding orbital of $\mathrm{P}-\mathrm{N}$ (exocyclic). Overlap stabilizes the exocyclic group in the axial position, and as a result the $\mathrm{P}=\mathrm{O}$ group is found in the equatorial position. ${ }^{47}$

Furthermore, there are some reports of preferred conformations driven by the repulsion of electrons in a molecule. As a typical example, we note the anti-orientation of the lone electron pair (LEP) located at the tertiary nitrogen atoms with respect to the $\mathrm{P}=$ $\mathrm{O}$ group in $[R \mathrm{C}(\mathrm{O}) \mathrm{NH}] \mathrm{P}(\mathrm{O})\left[\mathrm{N} R^{1} R^{2}\right]_{2}$ phosphoric triamides $\left(R^{1} \& R^{2}\right.$ $\neq \mathrm{H}$ ). The "empirical rule" reported in the published paper is related to the existence of $\mathrm{N}$ atoms with considerable differences in

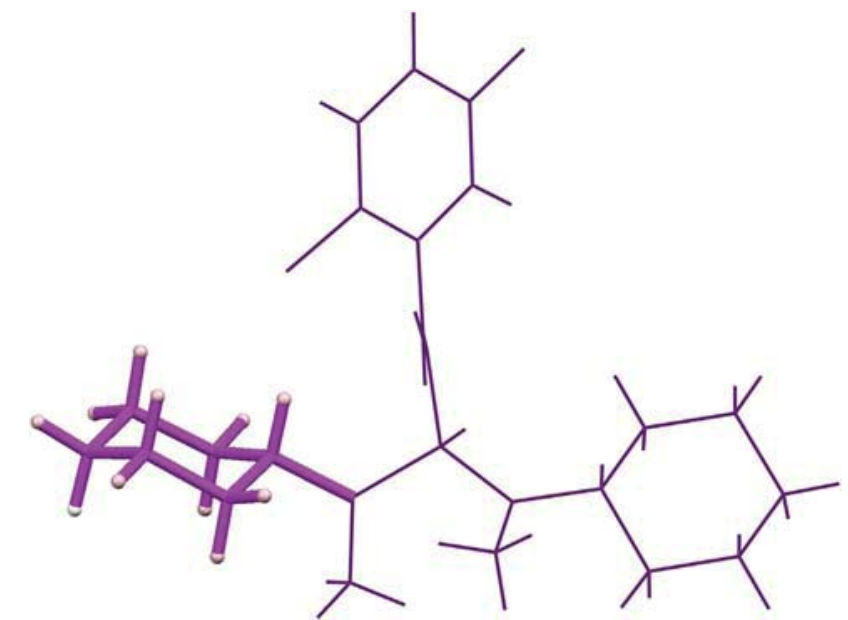

Fig. 14. The bulky $\mathrm{N}\left(\mathrm{CH}_{3}\right) \mathrm{P}(\mathrm{O})\left[\mathrm{N}\left(\mathrm{CH}_{3}\right)\left(\mathrm{C}_{6} \mathrm{H}_{11}\right)\right]\left[\mathrm{NHC}(\mathrm{O})\left(2-\mathrm{Cl}-5-\mathrm{F}-\mathrm{C}_{6} \mathrm{H}_{3}\right)\right]$ group in the equatorial position of the cyclohexyl ring in compound $\mathbf{6}$.

the valence-angle values, $\Delta \mathrm{SUM}=\mathrm{SUM} 1-\mathrm{SUM} 2>6^{\circ}$, and the anti-orientation with respect to $\mathrm{P}=\mathrm{O}$ for the LEP of the $\mathrm{N}$ atom in a more pyramidal environment $(\mathrm{SUMi}=\mathrm{C}-\mathrm{N}-\mathrm{P}+\mathrm{P}-\mathrm{N}-\mathrm{C}+\mathrm{C}-\mathrm{N}-\mathrm{C}$, $\mathrm{i}=1$ and 2 for two $\mathrm{N}$ atoms). ${ }^{34}$

For the discussion presented here, we consider the rings from the CSD and those of the new structures 1 to 6 . When we compare a typical " $\mathrm{C6}$ " skeleton with the " $\mathrm{C} 5 \mathrm{~N}$ " counterpart, the $\mathrm{N}$ heteroatom causes a perturbation in the bond lengths $(\mathrm{C}-\mathrm{C}$ versus $\mathrm{C}-\mathrm{N})$ and bond angles $(\mathrm{C}-\mathrm{C}-\mathrm{C}$ and $\mathrm{C}-\mathrm{N}-\mathrm{C})$. These differences cause deviation of rings including a heteroatom, but their influences on the conformation are low, however, as was noted earlier, in the case of some non-C atoms in the skeleton, for example in the "C3N2P" structures, the conformation completely changes from the ideal chair conformation of a "C6" ring.

The other stereoelectronic parameter is related to the difference in the hybridization of the carbon of the $\mathrm{C}-\mathrm{N}$ segment and the nitrogen of the $\mathrm{N}-\mathrm{P}$ segment which influences the bond angles.

\subsubsection{Steric effects}

For a typical structure 6 , the deviation of about $2.8^{\circ}$ in $\theta$ from the ideal $0^{\circ} / 180^{\circ}$ value of a cyclohexane ring is mainly due to the bulk effect of the $\mathrm{N}\left(\mathrm{CH}_{3}\right) \mathrm{P}(\mathrm{O})\left[\mathrm{N}\left(\mathrm{CH}_{3}\right)\left(\mathrm{C}_{6} \mathrm{H}_{11}\right)\right]\left[\mathrm{NHC}(\mathrm{O})\left(2-\mathrm{Cl}-5-\mathrm{F}-\mathrm{C}_{6} \mathrm{H}_{3}\right)\right]$ group in the equatorial position of the remaining cyclohexyl ring (Fig. 14). The deviations of $\theta$ values were previously discussed for new structures, and for a high bulk effect on the CSD, we note the structure with the CSD refcode DECTUB $\left(\mathrm{C}_{16} \mathrm{H}_{35} \mathrm{~N}_{2} \mathrm{O}_{13.50} \mathrm{P}_{4} \mathrm{Zn}_{3}\right)^{48}$ with $\theta$ of $4.6^{\circ}$ for the aliphatic six-membered ring.

\subsubsection{Packing effect and Hirshfeld surface analysis}

For a better investigation of the packing effect and intermolecular interaction on the conformational behavior, we decided to perform a Hirshfeld surface (HS) analysis. This analysis uses threedimensional (3D) surface functions for comparing the intermolecular contacts with respect to the van der Waals radii through a simple red-white-blue color coding scheme. In the Hirshfeld surfaces, red regions indicate intermolecular contacts with distances closer than the sum of the van der Waals radii, while blue and white areas are related to the contacts with distances longer than and equal to the sum of the van der Waals radii, respectively. ${ }^{49}$ Here, the HSs of compounds 1-6 are determined using the Crystal Explorer 3.1 program, ${ }^{50}$ as presented in Figs. 15, S1 and S2.

In these maps, the most prominent features are the deep red spots due to the $\mathrm{N}_{\mathrm{CP}}-\mathrm{H} \cdots \mathrm{O}_{\mathrm{P}}$ hydrogen bonds for all compounds 


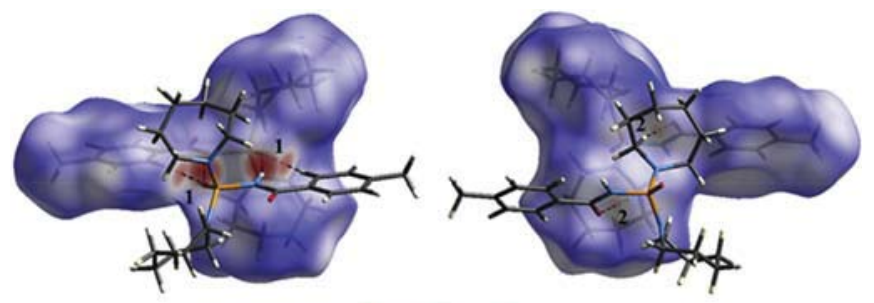

Structure 3

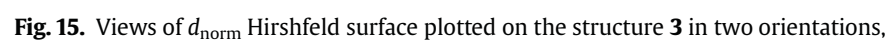
surrounded by neighboring molecules associated with close contacts. Labels on HS are as follows: P1-01[ $\cdots \mathrm{H} 1 \mathrm{~N}-\mathrm{N} 1][\cdots \mathrm{H} 3-\mathrm{C} 3](\mathbf{1})$ and $\mathrm{C} 9-\mathrm{H} 9 \mathrm{~A} \cdots \mathrm{O} 2(\mathbf{2})$.

except compound 2, and the $(\mathrm{N}-\mathrm{H} \cdots)_{2} \mathrm{O}_{\mathrm{P}}$ hydrogen bond for compound 2 (Table 5). Moreover, the other characteristic $(\mathrm{N}-\mathrm{H} \cdots)_{2} \mathrm{O}_{\mathrm{C}}$ and $\mathrm{N}_{\mathrm{CP}}-\mathrm{H} \cdots \mathrm{O}_{\mathrm{C}}$ hydrogen bonds which only exist respectively in compounds $\mathbf{1}$ and $\mathbf{2}$ are visible as light red spots in Fig. S1. In addition to the noted interactions, there are also some pale red spots on the HSs of compounds 3, 5 and $\mathbf{6}$, which reflect $\mathrm{C}-\mathrm{H} \cdots \mathrm{O}_{\mathrm{p}}$ interactions (Figs. 15 and $\mathrm{S} 2$ ), with the $\mathrm{CH}$ related to the benzoyl ring. Interestingly, there is also an interaction between a hydrogen atom of the $\mathrm{NC}_{6} \mathrm{H}_{12}$ ring with the carbonyl group in $\mathbf{3}$ (C9-H9A …02, label 2 in Fig. 15). Such an interaction in compounds $\mathbf{1}$ and $\mathbf{2}$ with the seven-membered aliphatic rings seems to be absent. It can be concluded that the observed twist-sofa conformation in compound $\mathbf{3}$ with respect to the almost chair conformation in $\mathbf{1}$ and 2 may result from this intermolecular interaction.

\subsection{IR and NMR study}

IR: For compounds 3-6, the unique $\mathrm{N}-\mathrm{H}$ unit of the $\mathrm{C}(\mathrm{O}) \mathrm{NHP}(\mathrm{O})$ segment takes part in the $\mathrm{N}-\mathrm{H} \cdots \mathrm{O}=\mathrm{P}$ hydrogen bond, while for compounds 1 and 2 (including three NH units) the $\mathrm{N}-\mathrm{H} \cdots \mathrm{O}=\mathrm{P}$ and $\mathrm{N}-\mathrm{H} \cdots \mathrm{O}=\mathrm{C}$ hydrogen bonds are present in the solid state (supported by X-ray crystallography data).

Stretching frequencies of the $\mathrm{N}-\mathrm{H}$ units occur at 3136, $3344 \mathrm{~cm}^{-1}$ for $\mathbf{1}, 3273 \mathrm{~cm}^{-1}$ for $\mathbf{2}$, and at 3096,3050 and $3042 \mathrm{~cm}^{-1}$ for 3,5 and 6, respectively. For compound 4, some weak bands present in the range of $3002-3105 \mathrm{~cm}^{-1}$, and probably the highest frequency should be assigned to the $\mathrm{NH}$ stretching vibration.

For 1, the lower stretching frequency is related to $\mathrm{N}_{\mathrm{CP}}-\mathrm{H}$, engaged in a hydrogen bonding interaction with the $\mathrm{P}=\mathrm{O}$ group (with a greater hydrogen bond strength with respect to the $\mathrm{N}_{\mathrm{P}}-\mathrm{H} \cdots \mathrm{O}=\mathrm{C}$ hydrogen bond), as demonstrated by a comparison of the IR spectra in analogous compounds and supported by quantum chemical calculations. ${ }^{44}$ The stretching frequency assigned to the $\mathrm{N}_{\mathrm{CP}}-\mathrm{H}$ vibration shows a blue shift in $\mathbf{2}$ with respect to that of $\mathbf{1}$, due to the weaker intermolecular $\mathrm{N}_{\mathrm{CP}}-\mathrm{H} \cdots \mathrm{O}=\mathrm{C}$ hydrogen bond in 2 compared to the $\mathrm{N}_{\mathrm{CP}}-\mathrm{H} \cdots \mathrm{O}=\mathrm{P}$ hydrogen bond in $\mathbf{1}$. This band includes a shoulder in the higher frequency attributed to the $\mathrm{N}_{\mathrm{P}}-\mathrm{H}$ units. The reason for the vicinity/overlap of $\mathrm{NH}$ bands in $\mathbf{2}$ is related to the closeness of hydrogen bond strengths formed (Table 5). Figs. S3-S8 indicate the IR spectra of compounds $\mathbf{1 - 6}$.

NMR: For compounds $\mathbf{1}-\mathbf{6}$, the ${ }^{31} \mathrm{P}$ signals are in the range of 6.25-13.67 ppm. The ${ }^{19} \mathrm{~F}$ chemical shifts reveal at $-113.58 \mathrm{ppm}$ (for compound 2 with $\mathrm{CF}_{3}$ moiety), -114.40 and $-114.29 \mathrm{ppm}$ (for compounds 5 and 6 with a 2-Cl,5-F- $\mathrm{C}_{6} \mathrm{H}_{3}$ moiety).

In the ${ }^{1} \mathrm{H}$ NMR spectra of all compounds, the broad signals in the range of 8.61-9.77 ppm are related to the corresponding $C(O)$ $\mathrm{NHP}(\mathrm{O})$ protons. Two chemically equivalent $\mathrm{N}-\mathrm{H}$ protons of the
$\mathrm{P}(\mathrm{O})\left(\mathrm{NHC}_{7} \mathrm{H}_{13}\right)_{2}$ segment in $\mathbf{1}$ appear as a triplet (at $4.20 \mathrm{ppm}$ ) because of the coupling at one hand with the $\mathrm{CH}$ unit of the sevenmembered ring and on the other hand with phosphorus. The signal of similar $\mathrm{N}-\mathrm{H}$ protons in compound $\mathbf{2}$ is revealed as a doublet at $2.51 \mathrm{ppm}$.

The 24 protons related to the azepane ring in $\mathbf{3}$ appear as three separate multiplet signals centered at $1.55,1.59$ and $3.11 \mathrm{ppm}$, which belong to the $\mathrm{H}-\mathrm{C}^{4} / \mathrm{H}-\mathrm{C}^{5}, \mathrm{H}-\mathrm{C}^{3} / \mathrm{H}-\mathrm{C}^{6}$ and $\mathrm{H}-\mathrm{C}^{2} / \mathrm{H}-\mathrm{C}^{7}$ of azepane, respectively and the integration area for each peak corresponds to eight protons.

The aromatic protons of the $\mathrm{CH}_{3}-\mathrm{C}_{6} \mathrm{H}_{4} \mathrm{C}(\mathrm{O})$ segment are revealed as two doublet signals at $7.27 \& 7.87 \mathrm{ppm}$ for $\mathbf{1}$ and at 7.26 \& 7.81 ppm for 3 , while the aromatic protons for the $2-\mathrm{Cl}, 5-\mathrm{F}-\mathrm{C}_{6} \mathrm{H}_{3}$ part in $\mathbf{5}$ and $\mathbf{6}$ are observed as multiplet signals in the range of 6.98-7.37 ppm, due to further coupling with fluorine.

In compound 6, the doublet signal at $2.64 \mathrm{ppm}$ belongs to the $\mathrm{CH}_{3}$-protons of the $\mathrm{N}\left(\mathrm{CH}_{3}\right)\left(\mathrm{C}_{6} \mathrm{H}_{11}\right)$ group, resulting from ${ }^{3} J_{\mathrm{P}-\mathrm{H}}$ coupling.

In the ${ }^{13} \mathrm{C}$ NMR spectra of $\mathbf{1}$ and $\mathbf{3}$, the carbon atom bound to the $\mathrm{C}=\mathrm{O}$ group (in the $\mathrm{CH}_{3}-\mathrm{C}_{6} \mathrm{H}_{4} \mathrm{C}(\mathrm{O})$ moiety) appears as a doublet signal due to the $3 \mathrm{~J}$ couplings with phosphorus. Also, the "dd" signals of similar a carbon atom in the 2-Cl,5-F- $\mathrm{C}_{6} \mathrm{H}_{3}$ moiety in $\mathbf{5}$ and $\mathbf{6}$ are related to phosphorus-carbon and fluorine-carbon couplings $\left({ }^{3} \mathrm{~J}\right)$. The other five carbon atoms of $2-\mathrm{Cl}, 5-\mathrm{F}-\mathrm{C}_{6} \mathrm{H}_{3}$ group appear as doublets (due to the coupling with fluorine) with ${ }^{1} J,{ }^{2} J,{ }^{3} J$ and ${ }^{4} J$ coupling constants as noted in the experimental section.

The signal for the $\mathrm{CF}_{3}$ carbon atom in $\mathbf{2}$ appears as a quartet of doublets, due to the coupling with fluorine and phosphorus nuclei $\left({ }^{1} J_{\mathrm{F}-\mathrm{C}}\right.$ and $\left.{ }^{3} \mathrm{~J}_{\mathrm{P}-\mathrm{C}}\right)$.

Compound 1 contains a $\mathrm{C}_{7} \mathrm{H}_{13} \mathrm{~N}$ moiety (" $\mathrm{C} 7$ " ring), which shows two ${ }^{3} \mathrm{~J}_{\mathrm{P}-\mathrm{C}}(6.1 \& 3.8 \mathrm{~Hz})$ coupling constants in the ${ }^{13} \mathrm{C}$ NMR spectrum. Compound 3 with a "C6N" ring shows both ${ }^{2} J_{\mathrm{P}-\mathrm{C}}(4.5 \mathrm{~Hz})$ and ${ }^{3} J_{\mathrm{P}-\mathrm{C}}(3.9 \mathrm{~Hz})$ coupling constants, too. Two signals are revealed for carbon atoms $C^{2}$, of the azepane part in 3 . To prove that the two observed signals stem either from a ${ }^{2} J_{P-C}$ coupling with a single chemical shift, or from two diastereotopic signals for $C^{2}$ and $C^{7}$ with both zero coupling to phosphorus, the spectrum was recorded in different magnetic fields, demonstrating the former supposition with $J=4.5 \mathrm{~Hz}$.

In compound 4 , carbon atoms of $C^{2} / \mathrm{C}^{6}$ and $\mathrm{C}^{3} / \mathrm{C}^{5}$ in the sixmembered ring ("C5N") are not equivalent, so, two different ${ }^{2} J_{P-C}$ and ${ }^{3} J_{\mathrm{P}-\mathrm{C}}$ coupling constants were obtained, ${ }^{3} J_{\mathrm{P}-\mathrm{C}}=4.7$ and $4.5 \mathrm{~Hz}>{ }^{2} J_{\mathrm{P}-\mathrm{C}}=3.1$ and $2.9 \mathrm{~Hz}$. The reason for the diastereotopic $\mathrm{C}$ atoms in $\mathbf{4}$ is the methyl group in the equatorial position, which restricts the flexibility of ring. Fig. 16 indicates the ${ }^{13} \mathrm{C}$ NMR spectrum of $\mathbf{4}$ in which two doublets at 33.98 and $34.15 \mathrm{ppm}$ (corresponding to ${ }^{3} J_{\mathrm{P}-\mathrm{C}}$ ) and two doublets at 44.23 and $44.43 \mathrm{ppm}$ (for ${ }^{2} J_{\mathrm{P}-\mathrm{C}}$ ) are shown. A similar result was observed in the ${ }^{13} \mathrm{C}$ NMR spectrum of molecule 5, i.e. ${ }^{3} J_{\mathrm{P}-\mathrm{C}}=4.5 \mathrm{~Hz}\left(\mathrm{C}^{3} / \mathrm{C}^{5}\right)>{ }^{2} \mathrm{~J}_{\mathrm{P}-\mathrm{C}}=3.0 \mathrm{~Hz}\left(\mathrm{C}^{2} / \mathrm{C}^{6}\right)$.

The doublet signals at 27.82, 30.86, 30.93 and $55.13 \mathrm{ppm}$ in 6 are assigned to the $\mathrm{C}^{7}\left({ }^{2} \mathrm{~J}_{\mathrm{P}-\mathrm{C}}=5.3 \mathrm{~Hz}\right), \mathrm{C}^{2}$ or $\mathrm{C}^{6}\left({ }^{3} \mathrm{~J}_{\mathrm{P}-\mathrm{C}}=2.3 \mathrm{~Hz}\right), \mathrm{C}^{6}$ or $\mathrm{C}^{2}$ $\left({ }^{3} J_{\mathrm{P}-\mathrm{C}}=3.8 \mathrm{~Hz}\right)$ and $\mathrm{C}^{1}\left({ }^{2} J_{\mathrm{P}-\mathrm{C}}=4.5 \mathrm{~Hz}\right)$, respectively. So, it can be concluded that 3 including seven-membered rings shows ${ }^{2} J_{\mathrm{P}-\mathrm{C}}$ greater than ${ }^{3} J_{\mathrm{P}-\mathrm{C}}$. A similar trend was found for the doublet carbon signals of $\mathbf{6}$ with a "C6" ring, while an opposite result was observed for 4 and 5 with a "C5N" ring $\left({ }^{2} J_{\mathrm{P}-\mathrm{C}}<{ }^{3} J_{\mathrm{P}-\mathrm{C}}\right)$.

Except for compounds $\mathbf{2}$ and $\mathbf{3}$, all other compounds present a singlet peak for the $C$ atom of the $C(O)$ group in the range of $161.59-168.35 \mathrm{ppm}$. The similar $\mathrm{C}$ atom in $\mathbf{2}$ is revealed as a quartet centered at $158.06 \mathrm{ppm}$ due to the coupling with three $\mathrm{F}$ atoms $\left({ }^{2} J_{\mathrm{F}-\mathrm{C}}=36.8 \mathrm{~Hz}\right)$, and for $\mathbf{3}$ the signal of this $\mathrm{C}$ atom is split as a doublet at $167.85 \mathrm{ppm}\left({ }^{2} \mathrm{~J}-\mathrm{C}=2.2 \mathrm{~Hz}\right)$. The numbering of carbon and proton atoms in the NMR assignments is according to Scheme 2. 


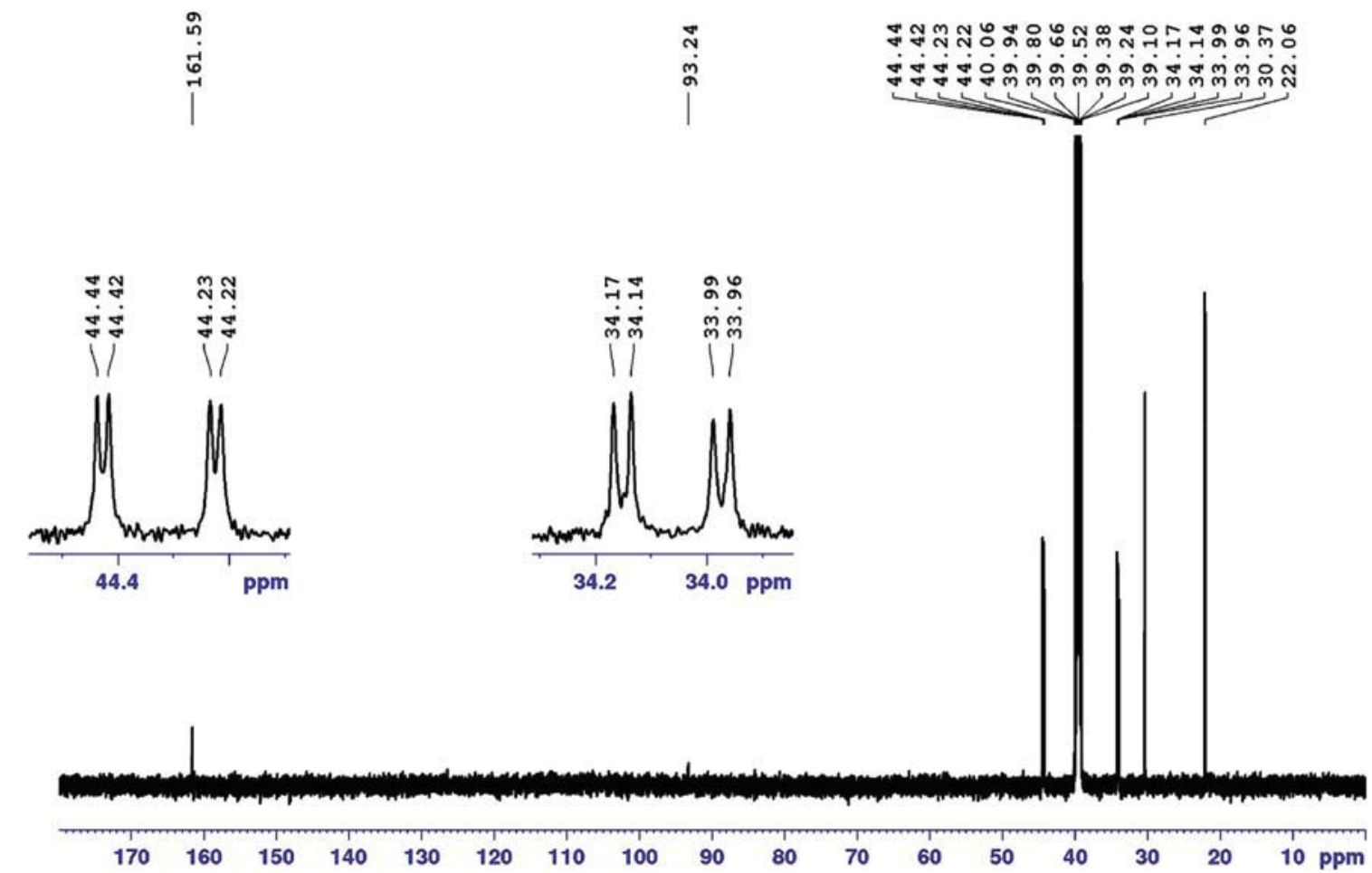

Fig. 16. The ${ }^{13} \mathrm{C}$ NMR spectrum of compound 4 in which two doublets at 33.98 and $34.15 \mathrm{ppm}$ (corresponding to ${ }^{3} J_{\mathrm{P}-\mathrm{C}}$ ) and two doublets at 44.23 and 44.43 ppm (for ${ }^{2} J_{\mathrm{P}-\mathrm{C}}$ ) are shown.

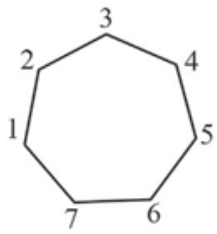

1 and 2

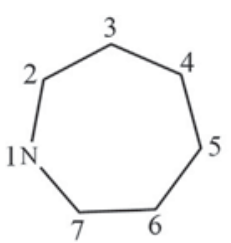

3

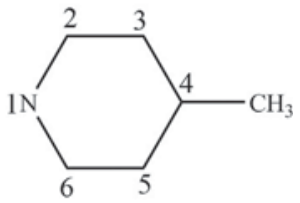

4

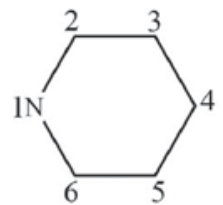

5

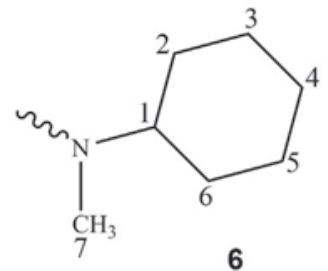

6

Scheme 2. The numbering of carbon atoms in aliphatic rings for NMR assignment of $\mathbf{1}-\mathbf{6}$.

\section{Conclusion}

Six new phosphoric triamide compounds containing cyclo- "C6" and "C5N" six-membered and cyclo- "C7" and "C6N" sevenmembered aliphatic rings have been studied by X-ray diffraction and spectroscopy. Then, the ring-puckering parameters and the conformations of the rings were determined and different factors were considered that may play a role in the conformational behavior. These factors are: (i) geometrical differences caused by the presence or absence of a heteroatom in the ring, (ii) steric effects, and (iii) crystal packing effects. The study was completed considering analogous structures in the CSD, including the rings with any sizes (three to seven). For new structures, the preferred conformation in aliphatic six-membered rings, cyclo- "C6" and

"C5N" is nearly chair. The structures with some non-carbon atoms, typically with a "C3N2P" segment, show conformation completely different from the ring with the same size only constructed from carbon atoms, e.g. "C6" in this case. In seven-membered rings, cyclo- "C7" and "C6N" with more flexibility, more diverse conformational forms are seen. The observed twist-sofa conformation in $\left(4-\mathrm{CH}_{3}-\mathrm{C}_{6} \mathrm{H}_{4} \mathrm{C}(\mathrm{O}) \mathrm{NH}\right) \mathrm{P}(\mathrm{O})\left(\mathrm{NC}_{6} \mathrm{H}_{12}\right)_{2}$ phosphoric triamide was ascribed to the packing effect which was investigated by a Hirshfeld surface analysis. The flexibility of seven-membered rings was also seen in analogous structures with "C6N" rings in the CSD and this is evidence for why such rings usually show disorder in the crystal structures. The two new structures with an $\mathrm{NHC}_{7} \mathrm{H}_{13}$ group, reported in this paper, are the first $\mathrm{C}(\mathrm{O}) \mathrm{NHP}(\mathrm{O})$-based phosphoric triamides including a " $\mathrm{C} 7$ " ring. For the small three- and fourmembered rings, the " $\mathrm{C} 2 \mathrm{~N}$ " ring is planar and the " $\mathrm{C} 3 \mathrm{~N}$ " ring is a squared creased and bent along its diagonal. Three skeletons were found for the five-membered rings: "C5", "C4N" and "C2N2P" with the calculated conformations as envelope for the first and half-chair for the second and third.

\section{Experimental}

\subsection{X-ray measurements}

Data were collected for all six structures using Mo-K $\alpha$ radiation, $\lambda=0.71073 \AA$ A . A STOE IPDS II diffractometer was used for $\mathbf{1}$ and $\mathbf{3}$, a Rigaku Saturn724+ diffractometer for 2, a Bruker SMART APEXII system for $\mathbf{4}$ and a Rigaku-Oxford Diffraction Gemini-S diffractometer for $\mathbf{5}$ and $\mathbf{6}$. The structures were solved with SHELXL2014/ $7^{51}$ for $\mathbf{1} \& \mathbf{3}$, SHELXS97 for $\mathbf{2}^{52} \& \mathbf{4}^{53}$ and SUPERFLIP ${ }^{54}$ for $\mathbf{5} \& \mathbf{6}$. The structures were refined using full matrix least squares on $F^{2}$ with the SHELXL2014 ${ }^{51}$ for $\mathbf{1} \& \mathbf{3}$, SHELXL97 ${ }^{55}$ for $\mathbf{2}$, SHELXL2014 $/ 7^{51}$ for 4 and CRYSTALS ${ }^{56}$ software packages for $5 \& \mathbf{6}$. The molecular drawings were generated with MERCURY ${ }^{57}$ and PLATON $-3^{12}$ for Windows. 


\subsection{Synthesis and crystallization}

The three starting materials $\left(4-\mathrm{CH}_{3}-\mathrm{C}_{6} \mathrm{H}_{4} \mathrm{C}(\mathrm{O}) \mathrm{NH}\right) \mathrm{P}(\mathrm{O}) \mathrm{Cl}_{2}$, $\left(\mathrm{CF}_{3} \mathrm{C}(\mathrm{O}) \mathrm{NH}\right) \mathrm{P}(\mathrm{O}) \mathrm{Cl}_{2}$ and $\left(\mathrm{CCl}_{3} \mathrm{C}(\mathrm{O}) \mathrm{NH}\right) \mathrm{P}(\mathrm{O}) \mathrm{Cl}_{2}$ were prepared according to the procedures described in the literature. ${ }^{58-60}(2-\mathrm{Cl}, 5-$ $\left.\mathrm{F}-\mathrm{C}_{6} \mathrm{H}_{3} \mathrm{C}(\mathrm{O}) \mathrm{NH}\right) \mathrm{P}(\mathrm{O}) \mathrm{Cl}_{2}$ was prepared by reflux of phosphorus pentachloride and 2-Cl,5-F- $\mathrm{C}_{6} \mathrm{H}_{3} \mathrm{C}(\mathrm{O}) \mathrm{NH}_{2}$ in $1: 1 \mathrm{M}$ ratio in dry $\mathrm{CCl}_{4}$ for $2 \mathrm{~h}$. Formic acid was added drop-wise by syringe into the cold solution under stirring $(2 \mathrm{~h})$ and the resulting fine white precipitate of product was gathered and dried in vacuo.

The synthesis of all compounds $\mathbf{1}-\mathbf{6}$ began with the reagents being mixed at ice-bath temperature and subsequent warming to room temperature. For the preparation of $\mathbf{1}$, a solution of cycloheptylamine ( $7.6 \mathrm{mmol})$ in dry $\mathrm{CHCl}_{3}(5 \mathrm{ml})$ was added to a solution of $4-\mathrm{CH}_{3}-\mathrm{C}_{6} \mathrm{H}_{4} \mathrm{C}(\mathrm{O}) \mathrm{NHP}(\mathrm{O}) \mathrm{Cl}_{2}(1.9 \mathrm{mmol})$ in the same solvent $(20 \mathrm{ml})$ at $273 \mathrm{~K}$ and stirred for $4 \mathrm{~h}$. After completion of the reaction, the solvent was removed in vacuo and the solid obtained was washed with $\mathrm{H}_{2} \mathrm{O}$. Compound 2 was prepared in a similar procedure but by using $\mathrm{CF}_{3} \mathrm{C}(\mathrm{O}) \mathrm{NHP}(\mathrm{O}) \mathrm{Cl}_{2}$ instead of $4-\mathrm{CH}_{3}-\mathrm{C}_{6} \mathrm{H}_{4} \mathrm{C}(\mathrm{O})$ $\mathrm{NHP}(\mathrm{O}) \mathrm{Cl}_{2}$. Colorless single crystals suitable for X-ray analysis were obtained at room temperature from a mixture of $\mathrm{CHCl}_{3} / \mathrm{C}_{7} \mathrm{H}_{16}(4: 1$ $v / v)$ for $\mathbf{1}$ and $\mathrm{CH}_{3} \mathrm{OH} / \mathrm{CHCl}_{3}(4: 1 v / v)$ for 2 .

For the synthesis of $\mathbf{3}$, a solution of hexamethylene imine $(8.0 \mathrm{mmol})$ in dry $\mathrm{CHCl}_{3}(10 \mathrm{ml})$ was added to a solution of (4$\left.\mathrm{CH}_{3}-\mathrm{C}_{6} \mathrm{H}_{4} \mathrm{C}(\mathrm{O}) \mathrm{NH}\right) \mathrm{P}(\mathrm{O}) \mathrm{Cl}_{2}(2.0 \mathrm{mmol})$ in the same solvent $(20 \mathrm{ml})$ at $273 \mathrm{~K}$. After stirring for $4 \mathrm{~h}$, the solvent was removed in vacuo and the solid obtained was washed with distilled water. Compound 4 was obtained by applying a similar procedure as for $\mathbf{3}$ but by using 4-methylpiperidine (7.2 mmol) and $\mathrm{CCl}_{3} \mathrm{C}(\mathrm{O}) \mathrm{NHP}(\mathrm{O}) \mathrm{Cl}_{2}(1.8 \mathrm{mmol})$. Colorless single crystals suitable for $\mathrm{X}$-ray analysis were obtained at room temperature from a mixture of $\mathrm{CH}_{3} \mathrm{OH} / \mathrm{CHCl}_{3}(4: 1 \mathrm{v} / \mathrm{v})$ for both 3 and 4.

For the synthesis of $\mathbf{5}$, a solution of piperidine $(8.0 \mathrm{mmol})$ in dry $\mathrm{CH}_{3} \mathrm{CN}(10 \mathrm{ml})$ was added to a solution of $2-\mathrm{Cl}, 5-\mathrm{F}-\mathrm{C}_{6} \mathrm{H}_{3} \mathrm{C}(\mathrm{O})$ $\mathrm{NHP}(\mathrm{O}) \mathrm{Cl}_{2}(2.0 \mathrm{mmol})$ in the same solvent $(20 \mathrm{ml})$ at $273 \mathrm{~K}$. After stirring for $4 \mathrm{~h}$, the solvent was removed in vacuo and the solid obtained was washed with distilled water. Compound 6 was obtained through a similar procedure as for $\mathbf{5}$ but by using N-methylcyclohexylamine. Colorless single crystals suitable for X-ray analysis were obtained at room temperature from a mixture of $\mathrm{CH}_{3} \mathrm{OH} / \mathrm{CHCl}_{3}(4: 1 v / v)$ for both 5 and $\mathbf{6}$.

\subsection{Structure refinement}

For 1, 2, 3 and 4, all carbon bound H-atoms were placed at calculated positions and were refined as riding on their parent atoms with their $U_{\text {iso }}$ set to $1.5 U_{\text {eq }}$ for the methyl group (in 1,3 and 4) or $1.2 U_{\text {eq }}$ for the other carbon atoms. Nitrogen bound H-atoms were located in a difference Fourier map and refined isotropically, with their $U_{\text {iso }}$ set to $1.2 U_{\text {eq }}$ of the carrier $\mathrm{N}$-atoms. For $\mathbf{1}$, the $\mathrm{N}-\mathrm{H}$ bond distances were restrained to be $0.91 \AA$, with an e.s.d. of $0.02 \AA$. The ring containing $\mathrm{C} 9 \mathrm{~A}$ and $\mathrm{C} 9 \mathrm{~B}$ has been split and refined to relative occupancy factors of 0.614 (4):0.386 (4). The different atoms in the ring were initially refined with restraints on the bond lengths to regularise their geometries $(\mathrm{C}-\mathrm{C}$ in the range $1.50-1.52 \AA$ with an e.s.d. of $0.02 \AA$ ) and some soft restraints have been applied to the displacement parameter to the atoms constituting the different rings. For 2 , the $\mathrm{N}-\mathrm{H}$ bond distances were restrained to $0.88 \AA$, with an e.s.d. of $0.01 \AA$. For 4 , the $\mathrm{N}-\mathrm{H}$ bond distance was restrained to $0.86 \AA$. For 3 , the $\mathrm{N}-\mathrm{H}$ bond distance was refined with riding constraints $(0.91 \AA$, with an e.s.d. of $0.01 \AA$ ) and also the atomic displacement parameters of C11 and C12 were constrained to be equal. For $\mathbf{5}$ and $\mathbf{6}$, the $\mathrm{H}$-atoms were all located in a difference map, but those attached to carbon atoms were repositioned geometrically. The $\mathrm{H}$-atoms were initially refined with soft restraints on the bond lengths and angles to regularise their geometries $(\mathrm{C}-\mathrm{H}$ in the range $0.93-0.98$ and $\mathrm{N}-\mathrm{H}$ in the range $0.86-0.89 \AA$ ) and $U_{\text {iso }}(\mathrm{H})=1.5 U_{\text {eq }}\left(C_{\mathrm{i}}\right)$ for methyl, $1.2 U_{\text {eq }}\left(C_{\text {ii }}\right)$ for the other carbon atoms and $1.2 U_{\mathrm{eq}}(\mathrm{N})$ for nitrogen, after which the positions were refined with riding constraints, except the nitrogen bound $\mathrm{H}$ atoms which were continued to be refined with soft restraints on distances and angles.

\subsection{NMR, IR and mass analysis}

For 1. Colorless rectangular block crystal. M.p. $190^{\circ} \mathrm{C}$. Anal. Calc. for $\left(\mathrm{C}_{22} \mathrm{H}_{36} \mathrm{~N}_{3} \mathrm{O}_{2} \mathrm{P}\right)(\%): \mathrm{C}=65.16 ; \mathrm{H}=8.95 ; \mathrm{N}=10.36$; found: $\mathrm{C}=65.10 ; \mathrm{H}=8.91 ; \mathrm{N}=10.32 . \mathrm{IR}\left(\mathrm{KBr}, \mathrm{cm}^{-1}\right): 3344,3136,2923$, 2854, 1643, 1565, 1520, 1448, 1278, 1219, 1187, 1070, 949, 888, 835, 748, 687. ${ }^{31} \mathrm{P}\left\{{ }^{1} \mathrm{H}\right\}$ NMR $\left(122 \mathrm{MHz}\right.$, DMSO- $\left.d_{6}\right): \delta=6.25(s) .{ }^{1} \mathrm{H}$ NMR $\left(301 \mathrm{MHz}, \mathrm{DMSO}-d_{6}\right): \delta=1.27-1.86(m, 24 \mathrm{H}), 2.34\left(s, 3 \mathrm{H}, \mathrm{CH}_{3}\right)$, 3.16-3.22 (m, 2H, CH), $4.20(t, J=9.5 \mathrm{~Hz}, 2 \mathrm{H}, \mathrm{NH}), 7.27(d$, $\left.{ }^{3} J_{\mathrm{H}-\mathrm{H}}=7.8 \mathrm{~Hz}, 2 \mathrm{H}, \mathrm{Ar}-\mathrm{H}\right), 7.87\left(d,{ }^{3} \mathrm{~J}_{\mathrm{H}-\mathrm{H}}=8.1 \mathrm{~Hz}, 2 \mathrm{H}, \mathrm{Ar}-\mathrm{H}\right), 8.99(\mathrm{~s}$, $1 \mathrm{H}, \mathrm{CONH}) .{ }^{13} \mathrm{C}$ NMR $\left(76 \mathrm{MHz}\right.$, DMSO- $\left.d_{6}\right): \delta=21.45(s), 23.82(\mathrm{~s})$, $23.90(s), 24.12(s), 24.46(s), 27.92(s), 28.09(s), 28.12(s), 28.25(s)$, $34.85(s), 37.32\left(d,{ }^{3} J_{\mathrm{P}-\mathrm{C}}=3.8 \mathrm{~Hz}, \mathrm{C}^{2} / \mathrm{C}^{7}\right), 37.61\left(d,{ }^{3} \mathrm{~J}_{\mathrm{P}-\mathrm{C}}=6.1 \mathrm{~Hz}, \mathrm{C}^{2}\right.$ ) $\left.C^{7}\right), 51.99(s), 52.04(s), 52.67(s), 128.49(s), 129.59(s), 131.68(d$, $\left.{ }^{3} \mathrm{~J}_{\mathrm{P}-\mathrm{C}}=8.3 \mathrm{~Hz}\right), 142.39(\mathrm{~s}), 168.35(\mathrm{~s})$. MS (70 eV, EI): $\mathrm{m} / \mathrm{z}(\%)=405$ (4) $[\mathrm{M}]^{+}, 404(38)[\mathrm{M}-1]^{+}, 288(5)\left[\mathrm{M}-4-\mathrm{CH}_{3}-\mathrm{C}_{6} \mathrm{H}_{4} \mathrm{CN}\right]^{+}, 134$ (58) $\left[\mathrm{C}_{8} \mathrm{H}_{8} \mathrm{NO}\right]^{+}, 119(73)\left[\mathrm{C}_{8} \mathrm{H}_{7} \mathrm{O}\right]^{+}, 117(91)\left[\mathrm{C}_{8} \mathrm{H}_{7} \mathrm{~N}\right]^{+}, 112(85)$ $\left[\mathrm{C}_{7} \mathrm{H}_{14} \mathrm{~N}\right]^{+}, 56(100)\left[\mathrm{C}_{4} \mathrm{H}_{8}\right]^{+}$.

For 2. Colorless block crystal. M.p. $145{ }^{\circ} \mathrm{C}$. Anal. Calc. for $\left(\mathrm{C}_{16} \mathrm{H}_{29} \mathrm{~F}_{3} \mathrm{~N}_{3} \mathrm{O}_{2} \mathrm{P}\right)(\%): \mathrm{C}=50.12 ; \mathrm{H}=7.62 ; \mathrm{N}=10.96$; found: $\mathrm{C}=49.98 ; \mathrm{H}=7.57 ; \mathrm{N}=10.92$. IR $\left(\mathrm{KBr}, \mathrm{cm}^{-1}\right): 3450,3273,2928$, 2858, 1716, 1631, 1464, 1426, 1311, 1202, 1163, 1074, 955, 894, 785, 705. ${ }^{31} \mathrm{P}\left\{{ }^{1} \mathrm{H}\right\}$ NMR $\left(122 \mathrm{MHz}\right.$, DMSO- $\left.d_{6}\right): \delta=6.32(s) .{ }^{19} \mathrm{~F}\left\{{ }^{1} \mathrm{H}\right\}$ NMR (283 MHz, $\left.\mathrm{CDCl}_{3}, \mathrm{CFCl}_{3}\right): \delta=-113.58(s) .{ }^{1} \mathrm{H} \mathrm{NMR}\left(301 \mathrm{MHz}, \mathrm{CDCl}_{3}\right)$ : $\delta=1.57-2.02(\mathrm{~m}, 24 \mathrm{H}), 2.51\left(\mathrm{~d},{ }^{2} \mathrm{~J}_{\mathrm{P}-\mathrm{H}}=9.9 \mathrm{~Hz}, 2 \mathrm{H}, \mathrm{NH}\right), 2.95(\mathrm{~b}, 2 \mathrm{H}$, $\mathrm{CH}), 9.59(\mathrm{~s}, 1 \mathrm{H}, \mathrm{CONH}) .{ }^{13} \mathrm{C}$ NMR $\left(76 \mathrm{MHz}\right.$, DMSO- $\left.d_{6}\right): \delta=23.84(\mathrm{~s})$, $28.08(s), 32.77(s), 51.89(s), 117.75\left(q d,{ }^{1} J_{\mathrm{F}-\mathrm{C}}=271.6 \mathrm{~Hz}\right.$, $\left.{ }^{3} \mathrm{~J}_{\mathrm{P}-\mathrm{C}}=6.8 \mathrm{~Hz}\right), 158.06\left(q,{ }^{2} \mathrm{~J}_{\mathrm{F}-\mathrm{C}}=36.8 \mathrm{~Hz}\right) . \mathrm{MS}(70 \mathrm{eV}, \mathrm{EI}): \mathrm{m} / \mathrm{z}$ $(\%)=382(2)[\mathrm{M}-1]^{+}, 287(7)\left[\mathrm{M}-\mathrm{CF}_{3} \mathrm{CNH}\right]^{+}, 270(2)$ $\left[\mathrm{M}-\mathrm{CF}_{3} \mathrm{C}(\mathrm{O}) \mathrm{NH}_{2}\right]^{+}, 112(77)\left[\mathrm{C}_{7} \mathrm{H}_{14} \mathrm{~N}\right]^{+}, 97(37)\left[\mathrm{C}_{2} \mathrm{~F}_{3} \mathrm{O}\right]^{+}, 95(35)$ $\left[\mathrm{C}_{2} \mathrm{~F}_{3} \mathrm{~N}\right]^{+}, 56(100)\left[\mathrm{C}_{4} \mathrm{H}_{8}\right]^{+}$.

For 3. Colorless cube crystal. M.p. $180{ }^{\circ} \mathrm{C}$. Anal. Calc. for $\left(\mathrm{C}_{20} \mathrm{H}_{32} \mathrm{~N}_{3} \mathrm{O}_{2} \mathrm{P}\right)(\%): \mathrm{C}=63.64 ; \mathrm{H}=8.55 ; \mathrm{N}=11.13$; found: $\mathrm{C}=63.39 ; \mathrm{H}=8.56 ; \mathrm{N}=11.10 . \mathrm{IR}\left(\mathrm{KBr}, \mathrm{cm}^{-1}\right): 3096,2923,1666$, 1614, 1443, 1330, 1268, 1233, 1187, 1107, 1060, 1005, 936, 876, 839, 747, 711. ${ }^{31} \mathrm{P}\left\{{ }^{1} \mathrm{H}\right\}$ NMR $\left(122 \mathrm{MHz}\right.$, DMSO-d $\left.d_{6}\right): \delta=12.56(s) .{ }^{1} \mathrm{H}$ NMR (500.13 MHz, DMSO- $\left.d_{6}\right): \delta=1.55-1.60$ (br. $\left.m, 16 \mathrm{H}\right), 2.35(s, 3 \mathrm{H}$, $\left.\mathrm{CH}_{3}\right), 3.01-3.18(m, 8 \mathrm{H}), 7.26\left(d,{ }^{3} \mathrm{~J}_{\mathrm{H}-\mathrm{H}}=7.5 \mathrm{~Hz}, 2 \mathrm{H}, \mathrm{Ar}-\mathrm{H}\right), 7.81(d$, $\left.{ }^{3} \mathrm{~J}_{\mathrm{H}-\mathrm{H}}=8.0 \mathrm{~Hz}, 2 \mathrm{H}, \mathrm{Ar}-\mathrm{H}\right), 8.95$ (v.br. $\left.1 \mathrm{H}, \mathrm{CONH}\right) .{ }^{13} \mathrm{C} \mathrm{NMR}$ $\left(125.76 \mathrm{MHz}\right.$, DMSO- $\left.d_{6}\right): \delta=20.88(s), 26.27(s), 29.74(d$, $\left.{ }^{3} J_{\mathrm{P}-\mathrm{C}}=3.9 \mathrm{~Hz}, \mathrm{C}^{3} / \mathrm{C}^{6}\right), 47.02\left(d,{ }^{2} \mathrm{~J}_{\mathrm{P}-\mathrm{C}}=4.5 \mathrm{~Hz}, \mathrm{C}^{2} / \mathrm{C}^{7}\right), 128.08(s)$, $128.68(s), 131.26\left(d,{ }^{3} J_{\mathrm{P}-\mathrm{C}}=8.6 \mathrm{~Hz}\right), 141.95(s), 167.85(d$, $\left.{ }^{2} J_{\mathrm{P}-\mathrm{C}}=2.2 \mathrm{~Hz}\right)$. MS $(70 \mathrm{eV}, \mathrm{EI}): \mathrm{m} / \mathrm{z}(\%)=378(18)[\mathrm{M}+1]^{+}, 377(56)$ $[\mathrm{M}]^{+}, 376(69)[\mathrm{M}-1]^{+}, 279(53)\left[\mathrm{M}-\mathrm{C}_{6} \mathrm{H}_{12} \mathrm{~N}\right]^{+}, 119(81)\left[\mathrm{C}_{8} \mathrm{H}_{7} \mathrm{O}\right]^{+}$, $117(54)\left[\mathrm{C}_{8} \mathrm{H}_{7} \mathrm{~N}\right]^{+}, 98(100)\left[\mathrm{C}_{6} \mathrm{H}_{12} \mathrm{~N}\right]^{+}$.

For 4. Colorless block crystal. M.p. $185{ }^{\circ} \mathrm{C}$. Anal. Calc. for $\left(\mathrm{C}_{14} \mathrm{H}_{25} \mathrm{Cl}_{3} \mathrm{~N}_{3} \mathrm{O}_{2} \mathrm{P}\right)(\%): \mathrm{C}=41.55 ; \mathrm{H}=6.23 ; \mathrm{N}=10.38$; found: $\mathrm{C}=41.82 ; \mathrm{H}=6.26 ; \mathrm{N}=10.32 . \mathrm{IR}\left(\mathrm{KBr}, \mathrm{cm}^{-1}\right): 3105,3002,2953$, 2923, 2851, 1728, 1453, 1383, 1355, 1291, 1225, 1202, 1161, 1117, 1068, $945,869,806,727,672 .{ }^{31} \mathrm{P}\left\{{ }^{1} \mathrm{H}\right\}$ NMR (243 MHz, DMSO-d $\left.d_{6}\right): \delta=9.30$ (s). ${ }^{1} \mathrm{H}$ NMR (601 MHz, DMSO- $\left.d_{6}\right): \delta=0.88\left(d,{ }^{3} J_{\mathrm{H}-\mathrm{H}}=6.6 \mathrm{~Hz}, 6 \mathrm{H}\right.$, $\left.\mathrm{CH}_{3}\right), 0.95-1.06(m, 4 \mathrm{H}), 1.41-1.50(m, 2 \mathrm{H}), 1.53-1.58(m, 4 \mathrm{H})$, $2.62-2.69(m, 4 \mathrm{H}), 3.37-3.46(m, 4 \mathrm{H}), 9.77(\mathrm{~s}, 1 \mathrm{H}, \mathrm{CONH}) .{ }^{13} \mathrm{C} \mathrm{NMR}$ $\left(151 \mathrm{MHz}\right.$, DMSO- $\left.d_{6}\right): \delta=22.06(s), 30.37(s), 33.98(d$, ${ }^{3} J_{\mathrm{P}-\mathrm{C}}=4.5 \mathrm{~Hz}, \mathrm{C}^{3}$ or $\left.\mathrm{C}^{5}\right), 34.15\left(d,{ }^{3} J_{\mathrm{P}-\mathrm{C}}=4.7 \mathrm{~Hz}, \mathrm{C}^{5}\right.$ or $\left.\mathrm{C}^{3}\right), 44.23(d$, ${ }^{2} J_{\mathrm{P}-\mathrm{C}}=2.9 \mathrm{~Hz}, \mathrm{C}^{2}$ or $\left.\mathrm{C}^{6}\right), 44.43\left(d,{ }^{2} J_{\mathrm{P}-\mathrm{C}}=3.1 \mathrm{~Hz}, \mathrm{C}^{6}\right.$ or $\left.\mathrm{C}^{2}\right), 93.24(\mathrm{~s})$, 161.59 (s). MS (70 eV, EI): m/z (\%) = $406(42)[\mathrm{M}+3]^{+}, 405(14)$ 
$[\mathrm{M}+2]^{+}, 404(1)[\mathrm{M}+1]^{+}, 307(10)\left[\mathrm{C}_{8} \mathrm{H}_{13}^{37} \mathrm{Cl}^{35} \mathrm{Cl}_{2} \mathrm{~N}_{2} \mathrm{O}_{2} \mathrm{P}\right]^{+}, 243(58)$ $\left[\mathrm{M}-\mathrm{C}^{35} \mathrm{Cl}_{3} \mathrm{C}(\mathrm{O}) \mathrm{NH}\right]^{+}, 162$ (16) $\left[\mathrm{C}_{2} \mathrm{H}^{37} \mathrm{Cl}^{35} \mathrm{Cl}_{2} \mathrm{NO}\right]^{+}, 147$ (58) $\left[\mathrm{C}_{2}^{37} \mathrm{Cl}^{35} \mathrm{Cl}_{2} \mathrm{O}\right]^{+}, 145(59)\left[\mathrm{C}_{2}^{37} \mathrm{Cl}^{35} \mathrm{Cl}_{2} \mathrm{~N}\right]^{+}, 100(100)\left[\mathrm{C}_{6} \mathrm{H}_{14} \mathrm{~N}\right]^{+}$.

For 5. Colorless prism crystal. M.p. $189{ }^{\circ} \mathrm{C}$. Anal. Calc. for $\left(\mathrm{C}_{17} \mathrm{H}_{24} \mathrm{ClFN}_{3} \mathrm{O}_{2} \mathrm{P}\right)(\%): \mathrm{C}=52.65 ; \mathrm{H}=6.24 ; \mathrm{N}=10.84$; found: $\mathrm{C}=52.43 ; \mathrm{H}=6.22 ; \mathrm{N}=10.79 . \mathrm{IR}\left(\mathrm{KBr}, \mathrm{cm}^{-1}\right): 3050,2933,2854$, 1690, 1579, 1482, 1450, 1340, 1297, 1193, 1112, 1072, 961, 844, 766, 725. ${ }^{31} \mathrm{P}\left\{{ }^{1} \mathrm{H}\right\}$ NMR $\left(122 \mathrm{MHz}, \mathrm{CDCl}_{3}\right): \delta=10.37(s) .{ }^{19} \mathrm{~F}\left\{{ }^{1} \mathrm{H}\right\} \mathrm{NMR}$ $\left(283 \mathrm{MHz}, \mathrm{CDCl}_{3}, \mathrm{CFCl}_{3}\right): \delta=-114.40(s) .{ }^{1} \mathrm{H} \mathrm{NMR}\left(301 \mathrm{MHz}, \mathrm{CDCl}_{3}\right)$ : $\delta=1.46-1.49(m, 12 \mathrm{H}), 3.07-3.09(m, 8 \mathrm{H}), 6.98-7.04(m, 1 \mathrm{H}, \mathrm{Ar}-\mathrm{H})$, 7.26-7.32 (m, 2H, Ar-H), $9.20(s, 1 \mathrm{H}, \mathrm{CONH}) .{ }^{13} \mathrm{C}$ NMR (76 MHz, $\left.\mathrm{CDCl}_{3}\right): \delta=24.55(s), 26.13\left(d,{ }_{\mathrm{P}-\mathrm{C}}=4.5 \mathrm{~Hz}, \mathrm{C}^{3} / \mathrm{C}^{5}\right), 45.60(d$, $\left.{ }^{2} J_{\mathrm{P}-\mathrm{C}}=3.0 \mathrm{~Hz}, \mathrm{C}^{2} / \mathrm{C}^{6}\right), 116.70\left(d,{ }^{2} J_{\mathrm{F}-\mathrm{C}}=25.0 \mathrm{~Hz}\right), 118.28(d$, $\left.{ }^{2} J_{\mathrm{F}-\mathrm{C}}=22.7 \mathrm{~Hz}\right), 126.08\left(d, J_{\mathrm{F}-\mathrm{C}}=3.0 \mathrm{~Hz}\right), 131.60\left(d, J_{\mathrm{F}-\mathrm{C}}=8.3 \mathrm{~Hz}\right)$, $136.93\left(d d,{ }^{3} J_{\mathrm{P}-\mathrm{C}}=9.8 \mathrm{~Hz},{ }^{3} J_{\mathrm{F}-\mathrm{C}}=6.8 \mathrm{~Hz}\right), 160.75\left(d,{ }^{1} J_{\mathrm{F}-\mathrm{C}}=248.2 \mathrm{~Hz}\right)$, $166.54(s)$. MS (70 eV, EI): $\mathrm{m} / \mathrm{z}(\%)=388(11)[\mathrm{M}+1]^{+}, 387(13)[\mathrm{M}]^{+}$, $386(42)[\mathrm{M}-1]^{+}, 157(39)\left[\mathrm{C}_{7} \mathrm{H}_{3}^{35} \mathrm{ClFO}\right]^{+}, 155(35)\left[\mathrm{C}_{7} \mathrm{H}_{3}^{35} \mathrm{ClFN}\right]^{+}, 131$ (57) $\left[\mathrm{C}_{5} \mathrm{H}_{10} \mathrm{NOP}\right]^{+}, 129(38)\left[\mathrm{C}_{6} \mathrm{H}_{3}^{35} \mathrm{ClF}\right]^{+}, 84(100)\left[\mathrm{C}_{5} \mathrm{H}_{10} \mathrm{~N}\right]^{+}$.

For 6. Colorless prism crystal. M.p. $198{ }^{\circ} \mathrm{C}$. Anal. Calc. for $\left(\mathrm{C}_{21} \mathrm{H}_{32} \mathrm{ClFN}_{3} \mathrm{O}_{2} \mathrm{P}\right)(\%): \mathrm{C}=56.82 ; \mathrm{H}=7.27 ; \mathrm{N}=9.47$; found: $\mathrm{C}=56.68 ; \mathrm{H}=7.31 ; \mathrm{N}=9.43 . \mathrm{IR}\left(\mathrm{KBr}, \mathrm{cm}^{-1}\right): 3042,2928,2857$, 1694, 1580, 1453, 1393, 1265, 1179, 1158, 1114, 1009, 980, 885, 856, 765, 642. ${ }^{31} \mathrm{P}\left\{{ }^{1} \mathrm{H}\right\}$ NMR $\left(122 \mathrm{MHz}, \mathrm{CDCl}_{3}\right): \delta=13.67(s) .{ }^{19} \mathrm{~F}\left\{{ }^{1} \mathrm{H}\right\} \mathrm{NMR}$ $\left(283 \mathrm{MHz}, \mathrm{CDCl}_{3}, \mathrm{CFCl}_{3}\right): \delta=-114.29(s) .{ }^{1} \mathrm{H} \mathrm{NMR}\left(301 \mathrm{MHz}, \mathrm{CDCl}_{3}\right)$ : $\delta=1.01-1.79(m, 20 \mathrm{H}), 2.64\left(d,{ }^{3} \mathrm{~J}_{\mathrm{P}-\mathrm{H}}=11.1 \mathrm{~Hz}, 6 \mathrm{H}, \mathrm{CH}_{3}\right), 3.34-3.46$ $(m, 2 \mathrm{H}), 7.03-7.10(m, 1 \mathrm{H}, \mathrm{Ar}-\mathrm{H}), 7.29-7.37(m, 2 \mathrm{H}, \mathrm{Ar}-\mathrm{H}), 8.61(\mathrm{~s}$, $1 \mathrm{H}, \mathrm{CONH}) .{ }^{13} \mathrm{C} \mathrm{NMR}\left(76 \mathrm{MHz}, \mathrm{CDCl}_{3}\right): \delta=25.62(s), 26.05(\mathrm{~s}), 26.06$ $(s), 27.82\left(d,{ }^{2} J_{\mathrm{P}-\mathrm{C}}=5.3 \mathrm{~Hz}, \mathrm{C}^{7}\right), 30.86\left(d,{ }^{3} \mathrm{JP}-\mathrm{C}=2.3 \mathrm{~Hz}, \mathrm{C}^{2}\right.$ or $\left.\mathrm{C}^{6}\right)$, $30.93\left(d,{ }^{3} J_{\mathrm{P}-\mathrm{C}}=3.8 \mathrm{~Hz}, \mathrm{C}^{6}\right.$ or $\left.\mathrm{C}^{2}\right), 55.13\left(d,{ }^{2} \mathrm{~J}_{\mathrm{P}-\mathrm{C}}=4.5 \mathrm{~Hz}, \mathrm{C}^{1}\right), 116.81$ $\left(d,{ }^{2} J_{\mathrm{F}-\mathrm{C}}=24.2 \mathrm{~Hz}\right), 118.38\left(d,{ }^{2} J_{\mathrm{F}-\mathrm{C}}=23.5 \mathrm{~Hz}\right), 125.85(d$, $\left.J_{\mathrm{F}-\mathrm{C}}=3.0 \mathrm{~Hz}\right), 131.64\left(d, J_{\mathrm{F}-\mathrm{C}}=7.6 \mathrm{~Hz}\right), 136.98\left(d d,{ }^{3} J_{\mathrm{P}-\mathrm{C}}=9.1 \mathrm{~Hz}\right.$, $\left.{ }^{3} J_{\mathrm{F}-\mathrm{C}}=6.8 \mathrm{~Hz}\right), 160.90\left(d,{ }^{1} \mathrm{~J}_{\mathrm{F}-\mathrm{C}}=248.9 \mathrm{~Hz}\right), 166.29(\mathrm{~s}) . \mathrm{MS}(70 \mathrm{eV}$, $\mathrm{EI}): \mathrm{m} / \mathrm{z}(\%)=445(25)[\mathrm{M}+2]^{+}, 444(48)[\mathrm{M}+1]^{+}, 443(25)[\mathrm{M}]^{+}$, 331 (12) $\left[\mathrm{M}-\mathrm{C}_{7} \mathrm{H}_{14} \mathrm{~N}\right]^{+}, 172$ (8) $\left[\mathrm{C}_{7} \mathrm{H}_{4}^{35} \mathrm{ClFNO}\right]^{+}, 157$ (42) $\left[\mathrm{C}_{7} \mathrm{H}_{3}^{35} \mathrm{ClFO}\right]^{+}, 155(68)\left[\mathrm{C}_{7} \mathrm{H}_{3}^{35} \mathrm{ClFN}\right]^{+}, 112(100)\left[\mathrm{C}_{7} \mathrm{H}_{14} \mathrm{~N}\right]^{+}$.

\section{Acknowledgements}

Support of this investigation by the Ferdowsi University of Mashhad (Project No. 39847/3) is gratefully acknowledged. We thank Dr. Devadasan Velmurugan, UGC BSR Faculty, CAS in Crystallography and Biophysics, University of Madras, Guindy Campus, Chennai -600025 , India for providing facilities to collect the data for compound 4. Dr. Abdul Ajees is thankful to Department of Science and Technology, Science and Engineering Research Board, India, for supporting the computational facilities through Grant SB/ FT/LS-273/2012. The Adolphe Merkle Foundation is gratefully acknowledged for funding the salary of Dr. Aurélien Crochet (for Xray crystallography analysis of $\mathbf{1}$ and $\mathbf{3}$ ) and supporting the machine pool. Part of this work was carried out with the support of X-ray diffraction and Bio-SAXS Core Facility of CEITEC (compound $\mathbf{2}$ ). We also acknowledge the Université de Montpellier for X-ray crystallographic facility of $\mathbf{5}$ and $\mathbf{6}$ and the University of Pittsburgh and University of Fribourg for NMR facilities.

\section{Appendix A. Supplementary data}

Supplementary data related to this article can be found at https://doi.org/10.1016/j.tet.2017.11.030.

\section{References}

1. Kessler H. Angew Chem Int Ed. 1982;21:512-523.

2. Kurosu H, Kawasaki M, Hirose M, Yamada M. J Phys Chem A. 2004;108: 4674-4678.
3. Mattern RH, Moore SB, Tran TA, Rueter JK, Goodman M. Tetrahedron. 2000;56: 9819-9831.

4. Todoroki Y, Nakano SI, Hirai N, Ohigashi H. Tetrahedron. 1996;52:8081-8098.

5. Yin R, Zhang W, Liu G, Wu P, Lau C, Li Y. Tetrahedron. 2016;72:3823-3831.

6. Sankar C, Umamatheswari S, Pandiarajan K. J Mol Struct. 2015;1083:27-38.

7. Goba I, Turovska B, Belyakov S, Liepinsh E. J Mol Struct. 2014:1074:549-558.

8. Yeh P-L, Tai C-K, Shih T-L, Hsiao H-L, Wang B-C. J Mol Struct. 2012;1018:64-71.

9. Kleinpeter E, Heydenreich M, Koch A, Linker T. Tetrahedron. 2012;68: 2363-2373.

10. Marcos PM, Proença CS, Teixeira FA, Ascenso JR, Bernardino RJ, Cragg PJ. Tetrahedron. 2013;69:7430-7437.

11. Domínguez Z, Galván M, Cortez MT, et al. Tetrahedron. 2010;66:2066-2076.

12. Spek AL. Acta Cryst. 2009;D65:148-155.

13. Plutecka A, Rychlewska U, Prusinowska N, Gawronski J. Acta Cryst. 2010;B66: 678-686.

14. Zefirov NS, Palyulin VA, Dashevskaya EE. J Phys Org Chem. 1990;3:147-158.

15. Shi YC, Duan HY. Acta Cryst. 2013;C69:1177-1180.

16. Beşli S, Coles SJ, Davarci D, Davies DB, Hursthouse MB, Kilic A. Polyhedron. 2007; $26: 5283-5292$

17. Beșli S, İbisoğlu H, Kılıc A, Ün İ, Yuksel F. Polyhedron. 2010;29:3220-3228.

18. Cremer D, Pople JA. J Am Chem Soc. 1975;97:1354-1358.

19. Kilpatrick JE, Pitzer KS, Spitzer R. J Am Chem Soc. 1947;69:2483-2488.

20. Cremer D. Acta Cryst. 1984;B40:498-500.

21. Boessenkool IK, Boeyens JCA. J Cryst Mol Struct. 1980;10:11-18.

22. Edmonds MK, Abell AD. J Org Chem. 2001;66:3747-3752.

23. François G, Passreite CM, Woerdenbag HJ, Van Looveren M. Planta Med. 1996;62:126-129.

24. Ganellin CR. J Med Chem. 1973;16:620-623.

25. Gholivand K, Pourayoubi M. Z Anorg Allg Chem. 2004:630:1330-1335.

26. Dehghanpour S, Welter R, Barry AH, Tabasi F. Spectrochim Acta Mol Biomol Spectrosc. 2010;75:1236-1243.

27. Raissi Shabari A, Pourayoubi M, Marandi P, Dušek M, Eigner V. Acta Cryst. 2015;C71:338-343.

28. Pourayoubi M, Toghraee M, Zhu J, Dušek M, Bereciartua PJ, Eigner V. CrystEngComm. 2014;16:10870-10887.

29. Quintero L, Sanchez-Vazquez M, Cruz-Gregorio S, Sartillo-Piscil F. J Org Chem. 2010;75:5852-5859.

30. Cruz-Gregorio S, Rodriguez-Palacios V, Höpfl H, Quintero L, Sartillo-Piscil F. J Org Chem. 2009;74:197-205.

31. Tarahhomi A, Pourayoubi M, Fejfarová K, Dušek M. Acta Cryst. 2013;C69: 225-228.

32. Pourayoubi M, Toghraee M, Divjakovic V, et al. Acta Cryst. 2013;B69:184-194.

33. Corbridge DEC. Phosphorus an Outline of its Chemistry, Biochemistry and Technology. fifth ed. Amsterdam: Elsevier; 1995.

34. Pourayoubi M, Jasinski JP, Shoghpour Bayraq S, et al. Acta Cryst. 2012;C68: 0399-0404.

35. Bernstein J, Davis RE, Shimoni L, Chang N-L. Angew Chem Int Ed Engl. 1995;34: 1555-1573.

36. Allen FH. Acta Cryst. 2002;B58:380-388.

37. Pourayoubi M, Tarahhomi A, Rheingold AL, Golen JA. Acta Cryst. 2014;C70: 998-1002.

38. Toghraee M, Pourayoubi M, Divjakovic V. Polyhedron. 2011:30:1680-1690.

39. Carey FA, Sandberg RJ. Advanced Organic Chemistry. fifth ed. Springer; 2007: 162.

40. Sorrell TN. Organic Chemistry. second ed. Sausalito, California: University Science Books; 2005:83.

41. Gholivand K, Hosseini Z, Pourayoubi M, Shariatinia Z. Z Anorg Allg Chem. 2005:631:3074-3079.

42. Cotton FA, Frenz BA. Tetrahedron. 1974;30:1587-1594.

43. Oroujzadeh N, Gholivand K, Shariatinia Z. Phosphorus Sulfur Silicon Relat Elem. 2013;188:183-191.

44. Pourayoubi M, Izadyar M, Elahi B, Parvez M. J Mol Struct. 2013;1034:354-362.

45. Hendrickson JB. J Am Chem Soc. 1967;89:7036-7043.

46. Bocian DF, Strauss HL. J Am Chem Soc. 1977;99:2866-2876.

47. Tarahhomi A, Pourayoubi M, Rheingold AL, Golen JA. Struct Chem. 2010;22: 201-210

48. Ying S-M, Mao J-G. J Mol Struct. 2006;783:13-20.

49. McKinnon JJ, Jayatilaka D, Spackman MA. Chem Commun. 2007:3814-3816.

50. Wolff SK, Grimwood DJ, McKinnon JJ, Turner MJ, Jayatilaka D, Spackman MA CrystalExplorer version 3.1. Perth: University of Western Australia; 2013.

51. Sheldrick GM. Acta Cryst. 2015;C71:3-8.

52. Sheldrick GM. In: Moras D, Podjarny AD, Thierry JC, eds. Crystallographic Computing 5: From Chemistry to Biology. 1991.

53. Sheldrick GM. Acta Cryst. 2008;A64:112-122.

54. Palatinus L, Chapuis G. J Appl Crystallogr. 2007:40:786-790.

55. Sheldrick GM. Methods Enzymol. 1997;276:628-641.

56. Betteridge PW, Carruthers JR, Cooper RI, Prout K, Watkin DJ. J Appl Cryst. 2003;36:1487.

57. Macrae CF, Bruno IJ, Chisholm JA, et al. J Appl Cryst. 2008;41:466-470.

58. Gholivand K, Mojahed F, Alizadehgan AM, Bijanzadeh H. Z Anorg Allg Chem. 2006:632:1570-1577.

59. Narula PM, Day CS, Powers BA, et al. Polyhedron. 1999;181:1751-1759.

60. Kirsanov AV, Derkach GI. Zhur Obshch Khim. 1956;26:2082-2085. 